\title{
Development of a quantitative risk assessment of bovine viral diarrhea virus and bovine herpesvirus-1 introduction in dairy cattle herds to improve biosecurity
}

\author{
B. Benavides, ${ }^{1,2 *}$ J. Casal, ${ }^{1,3}$ J. F. Diéguez, ${ }^{4}$ E. Yus, ${ }^{5}$ S. J. Moya, ${ }^{1}$ R. Armengol, ${ }^{6}$ and A. Allepuz ${ }^{1,3 *}$ \\ ${ }^{1}$ Departament de Sanitat i Anatomia Animals, Facultat de Veterinària, Cerdanyola del Vallès, 08193, Spain \\ ${ }^{2}$ Department of Animal Health, Universidad de Nariño, Pasto, 520002, Colombia \\ ${ }^{3}$ Centre de Recerca en Sanitat Animal (CReSA), Institut de Recerca i Tecnologia Agroalimentàries (IRTA), Cerdanyola del Vallès, 08193, Spain \\ ${ }^{4}$ Department of Anatomy and Animal Production, Universidad de Santiago de Compostela, Lugo, 15703, Spain \\ ${ }^{5}$ Department of Animal Pathology, Universidad de Santiago de Compostela, Lugo, 15703, Spain \\ ${ }^{6}$ Department of Animal Science, Universitat de Lleida, Lleida, 25002, Spain
}

\section{ABSTRACT}

A quantitative risk assessment model was developed to estimate the annual probability of introducing bovine viral diarrhea virus (BVDV) and bovine herpesvirus 1 (BoHV-1) at the farm level through animal movements. Data from 2017 official animal movements, biosecurity questionnaires, scientific literature, and expert opinion from field veterinarians were taken into consideration for model input parameters. Purchasing or introducing cattle, rearing replacement heifers offsite, showing cattle at competitions, sharing transport vehicles with other herds, and transporting cattle in vehicles that have not been cleaned and disinfected were considered in the model. The annual probability of introducing BVDV or BoHV-1 through infected animals was very heterogeneous between farms. The median likelihoods of BVDV and BoHV-1introduction were 12 and 9\%, respectively. Farms that purchased cattle from within their region (i.e., local movements) and shared transport with other farms had a higher probability for BVDV and BoHV-1 introduction. This model can be a useful tool to support decision-making on biosecurity measures that should be prioritized to reduce the probability of introduction of these 2 diseases in dairy herds. Key words: biosecurity, bovine viral diarrhea virus, bovine herpesvirus-1, epidemiology, risk assessment

\section{INTRODUCTION}

Bovine viral diarrhea (BVD), caused by BVD virus (BVDV), and infectious bovine rhinotracheitis (IBR) caused by bovine herpesvirus 1 (BoHV-1), are 2

Received October 31, 2019.

Accepted February 29, 2020.

*Corresponding authors: bibiana.benavides@e-campus.uab.cat and alberto.allepuz@uab.cat diseases of importance in dairy herds because of their effects on reproductive performance, increased susceptibility to other diseases, early culling, and subsequent economic losses (Hage et al., 1998; Muylkens et al., 2007; Newcomer and Givens, 2016). Animals infected by BVDV can be classified into 3 different infection statuses: (1) persistently infected (PI) cattle, which are animals vertically infected during early pregnancy (30 to $120 \mathrm{~d}$ ) and that shed large amounts of virus all their lives (Houe, 1999); (2) transiently infected (TI) cattle, which are animals horizontally infected after birth that shed small amounts of virus for up to 15 d (Houe, 1999; Niskanen et al., 2000); and (3) Trojan cows (TR), which are pregnant cows that carry a PI calf (Reardon et al., 2018). Cattle with BoHV-1 can develop acute infections (AcI) and shed the virus for a short time, followed by a latent infection (LI) for the rest of their lives, excreting the virus under stress conditions (Lazic et al., 2003). Cattle movements are considered the main routes of BVDV and BoHV-1 spread between herds (van Schaik et al., 1998, 2002; Lindberg and Alenius, 1999).

Several European countries have implemented compulsory and voluntary BVD and IBR control and eradication programs (Lindberg et al., 2006; Nardelli et al., 2008). The implementation of biosecurity is considered an essential pillar in these programs. Different studies have described biosecurity measures in cattle farms (e.g., Sahlström et al., 2014; Sarrazin et al., 2014a), and several methods have been developed to score different levels of biosecurity practices implemented on farms. Existing methods to evaluate biosecurity practices use checklists to support the development of on-farm biosecurity plans (https://www.farmbiosecurity.com.au) or to score the level of biosecurity measures implemented on farms based on measures that are common to the transmission of different types of infectious agents, such as Biocheck.UGent (Laanen et al., 2014). In addition, several studies have identified biosecurity gaps 
as risk factors associated with disease outbreaks and, therefore, have provided relevant information for disease prevention (e.g., Almeida et al., 2013; Machado et al., 2016). However, less attention has focused on the development of risk assessment models to evaluate the effect of biosecurity measures in the probability of disease introduction to support decision-making on which practices should be prioritized according to farm-specific risks. Biosecurity programs need to be flexible and adaptable to the particular situations on each farm (Wells, 2000; Brennan and Christley, 2012). In this context, quantitative risk assessment (Murray et al., 2004) can be a useful method to identify and justify the enhancement of biosecurity measures based on the probability of disease introduction.

The aim of the present study was to develop a quantitative risk assessment model to identify farm-specific biosecurity measures that should be implemented to reduce the probability of BVDV and BoHV-1 introduction into dairy cattle herds through animal movements.

\section{MATERIALS AND METHODS}

\section{Data}

A structured questionnaire was used to obtain data on biosecurity measures on 34 and 93 farms from Catalonia and Galicia, Spain, respectively, that voluntarily participated in the project. The biosecurity questionnaire (available in Spanish upon request) was structured in 4 parts: (1) general data of the farm; (2) animal movements (e.g., origin of the animals, frequency of introductions, test, quarantine facilities, external rearing farms, cattle fairs, pasture); (3) vehicles (e.g., vehicles entering inside farm perimeter, vehicles coming in with other animals); and (4) visitors and staff (e.g., external workers, frequency of visitors, use of protective clothing). The Autonomous Governments of Catalonia and Galicia provided records of cattle movements (national and international) for 2017. Movements were registered at the animal level and included the following information: calving date, movement date, country of origin, and a unique code of destination. Based on the calving date and movement date, the age of each purchased animal was calculated. For BVDV, we classified introduced cows and heifers into 1 of 3 groups: $(1)<12$ mo old, (2) from 12 to 24 mo old, and (3) > 24 mo old. Based on published reports, PI animals were classified into 1 of the first 2 groups, whereas TI animals could be classified into any group, and Trojan cows could only be classified into 1 of the last 2 groups. For BoHV-1, introduced cattle were classified into 1 of 2 groups (i.e., $<24 \mathrm{mo}, \geq 24 \mathrm{mo}$ ) because disease prevalence can vary by age (Mars et al., 2001; Lassen et al., 2012; Sayers et al., 2015). The pregnancy status of introduced animals and an estimate of their days of gestation were provided for each study farm.

\section{Risk Release Pathways}

Field veterinarians responsible for the health management of farms involved in the project were invited to participate in the development of the risk assessment model. One discussion group was organized to determine risk release pathways and risk-mitigating measures that should be included in the model. Five veterinarians attended a group discussion meeting (Appendix Table A1). After the group discussion, variables for introduction of new animals through purchase of cattle, movements of reared replacement heifers offsite, movements to cattle competitions, shared transport vehicles with others farms, and transport of cattle in vehicles that have not been properly cleaned and disinfected (i.e., contaminated transport vehicle) were considered for inclusion in the model. Movements to pasture were included in the biosecurity questionnaire but not considered in the model because it was not a common practice in dairy cattle in the area under study. In Figure 1, parameters considered in the pathway for the "purchase of animals" are shown. Parameters considered for the movement of animals to cattle competitions and reared replacement heifers offsite are presented in Appendix Figure A1 and Figure A2.

\section{Model Development}

To estimate the probability of introducing BVDV and BoHV-1 into a dairy cattle farm in a 12-mo period, a stochastic risk assessment model was developed using the mc2d package (Pouillot and Delignette-Muller, 2010) implemented in R (https://www.R-project.org/). Monte Carlo simulations (10,000 iterations) were performed, and all nonfixed input parameters were included as uncertain parameters.

\section{Probability of Purchasing an Infected Animal}

In the analysis, using the cattle movement database, the origins of cattle purchased from other farms included France, the Netherlands, Catalonia, Galicia, and the rest of Spain. Accordingly, cattle movements were classified into 1 of these 5 origins. We assumed that the number of cattle purchased in each batch throughout the year had the same number of animals. Therefore, the number of animals purchased each time (i.e., the size of the batch) from each country/area, group age 
and farm (data obtained from the biosecurity questionnaires) was calculated using equation [1] (Appendix Table A2).

The probability that at least one animal from a batch coming from a single farm of a certain country/ area was already infected with BVDV or BoHV-1 was estimated using equation [2] (Appendix Table A2). Herd and within-herd prevalence values were obtained through a literature review and personal contacts with experts from the countries. Values from Catalonia and Galicia were obtained from previous work conducted in these areas (Benavides et al., 2018). In the case of BVDV, herds with young cattle that tested seropositive or detection of the virus within cattle herds were considered indications that the virus was circulating in those herds.

In Table 1, the different input distributions used in the model are described. Probability distributions were used to account for uncertainty in parameter estimates. Uniform distributions were reported as minimum and maximum values, and they were used as inputs obtained from the literature (i.e., BVDV and BoHV-1 prevalence, diagnostic test performance, BVDV transmission probability). We used PERT distributions for BVDV survival in different materials where the minimum, maximum, and most likely values were the time in hours that the virus could survive.

The expected numbers of BVDV and BoHV-1 animals already infected in the farm of origin were calculated based on the probability that a single animal was infected, using equations [3.1] and [3.2] (Appendix Table A2). The expected number of uninfected animals for each age group was therefore obtained by subtracting the expected number of animals infected in each age group from the total number of purchased animals.

\section{Probability of False Negatives}

Based on group discussion with attending veterinarians, animals were routinely tested for the detection of BoHV-1 and BVDV antibodies by using an ELISA before cattle purchase. Using ELISA, positive antibody was considered useful for detection of TI, TR, or BoHV1 seropositive cattle, but not PI animals. For the sensitivity and specificity of the ELISAs, values reported by Hanon et al. (2018) and Raaperi et al. (2014) were used for the detection of BVDV and BoHV-1 antibodies, respectively. For the detection of PI antigen, the values for the ELISA antigen as reported by Mars and Van Maanen (2005) were used (Table 1). The probability that one infected animal yielded a false-negative result was calculated based on equation [4] (Appendix Table A2). Therefore, the probability that at least one infected animal was present in the batch of animals and the probability that at least one infected animal was purchased from at least one of the farms from which animals could be introduced were calculated using equations [5.1] and [5.2] (Appendix Table A2).

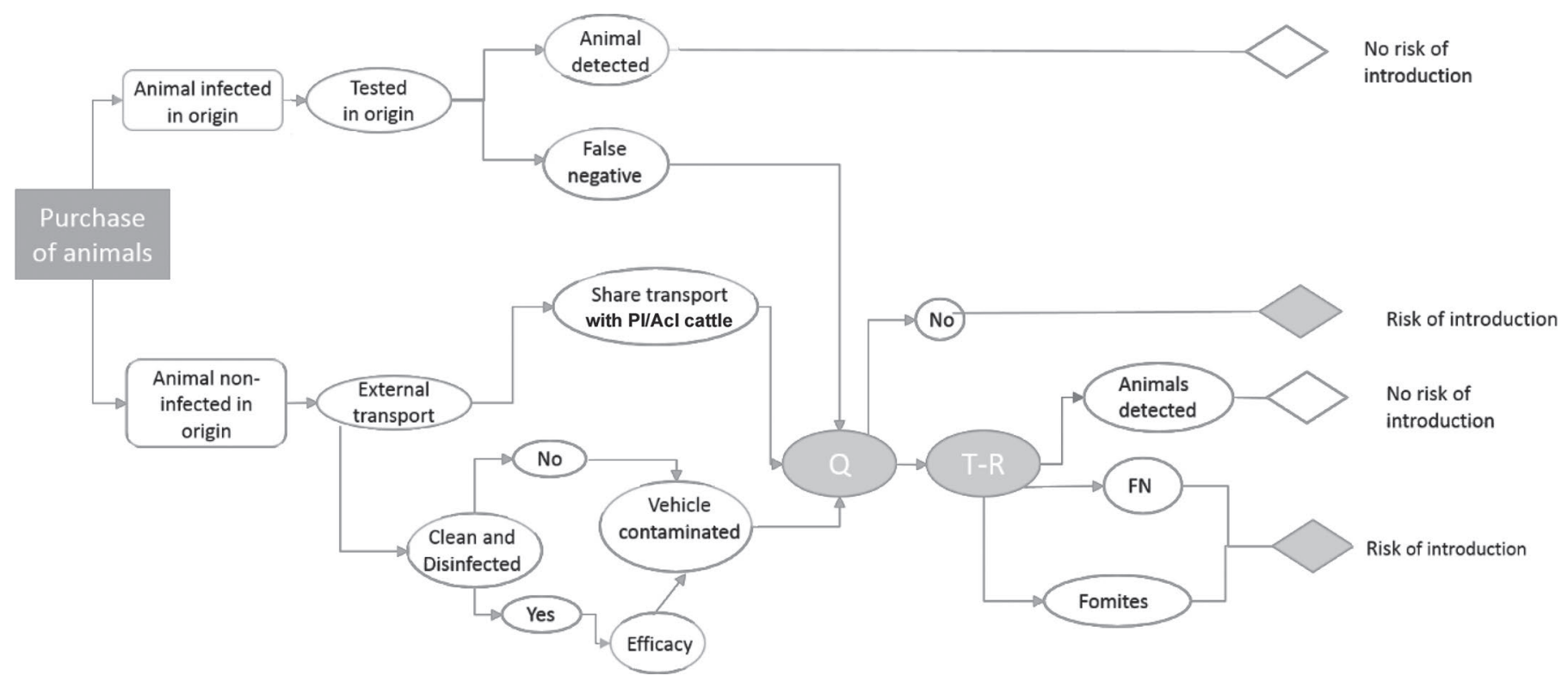

Figure 1. Pathway for bovine viral diarrhea virus (BVDV) and bovine herpesvirus-1 (BHV-1) introduction in dairy cattle herds through the purchase of animals; $\mathrm{Q}=$ quarantine; $\mathrm{T}=$ test on quarantine; $\mathrm{R}=$ quarantine routines; $\mathrm{PI}=$ persistently infected with BVDV; AcI = acutely infected with BHV-1; FN = false negative. 


\section{Probability of Infection During Transport from an Infected Animal}

Uninfected cattle could be infected during transport by sharing the transport vehicle either with a PI (for BVDV) or AcI (for BoHV-1) animal or by being transported in a contaminated vehicle. We excluded TI animals because the probability of transmission from a TI is very low (Table 1). The likelihood of contact with other cattle during the transport was obtained from the biosecurity questionnaires. Unfortunately, data on the number of farms attended by the same vehicle per day in the country/area of origin and the average number of animals transported in each movement were not available. Thus, based on group discussion with attending veterinarians, the maximum capacity of the vehicle was 36 animals, and several farms visited in each country/ area of origin ranging between 2 and 4 was considered. Therefore, the number of animals loaded by farm would be between 18 (in the case of 2 origins) and 9 (in the case of 4 origins). Equations [6.1] and [6.2] were used to calculate the probability of sharing a transport vehicle with a PI or AcI animal when purchasing animals from a country/area (Appendix Table A2).

Table 1. Input parameters, distribution, and values to estimate the probability of introduction to bovine viral diarrhea virus (BVDV) and bovine herpesvirus 1 (BoHV-1) in study farms

\begin{tabular}{|c|c|c|}
\hline Parameter & Distribution and values & Reference \\
\hline Herd prevalence in France & Uniform $(0.21-0.22)$ & Santman Berends et al., 2017 \\
\hline Herd prevalence in the Netherlands & Uniform $(0.16-0.18)$ & $\begin{array}{l}\text { van Duijn et al., 2019, Santman-Berends et } \\
\text { al., } 2015\end{array}$ \\
\hline Herd prevalence in Spain & Uniform $(0.26-0.71)$ & $\begin{array}{l}\text { Foddai et al., 2014; Gómez-Pacheco et al., } \\
2009\end{array}$ \\
\hline Herd prevalence in Catalonia & Uniform $(0.54-0.57)$ & Benavides et al., 2018 \\
\hline $\mathrm{PI}^{1}$ animal prevalence $(<12 \mathrm{mo})$ & Uniform $(0.0002-0.02)$ & Bachofen et al., 2013, Joly et al., 2005 \\
\hline PI animal prevalence (12 to $24 \mathrm{mo}$ ) & Uniform (0.0001-0.01) & Ezanno et al., 2007 \\
\hline Sensitivity of ELISA $\left(\mathrm{Abs}^{2}\right)$ & Uniform $(0.93-0.98)$ & Hanon et al., 2018 \\
\hline Specificity of ELISA (Abs) & Uniform $(0.94-0.99)$ & Hanon et al., 2018 \\
\hline Sensitivity of ELISA $\left(\mathrm{Ag}^{2}\right)$ & Uniform $(0.97-1)$ & Mars and Van Maanen, 2005 \\
\hline Specificity of ELISA (Ag) & Uniform (0.99-0.995) & Mars and Van Maanen, 2005 \\
\hline Sensitivity of PCR & Fixed value $(0.99)$ & Hilbe et al., 2007 \\
\hline Probability of transmission from $\mathrm{TI}^{3}$ animal & Uniform $(0.001-0.05)$ & Very low; DAFF, 2004 \\
\hline Probability of transmission from a PI animal & Fixed value $(0.66)$ & Niskanen and Lindberg, 2003 \\
\hline \multicolumn{3}{|l|}{ BoHV-1 } \\
\hline Herd prevalence in France & Uniform $(0.098-0.11)$ & Gache et al., 2014, GDS, 2017 \\
\hline Herd prevalence in the Netherlands & Uniform $(0.15-0.156)$ & SCOPAFF, 2018, GD Animal Health, 2018 \\
\hline Herd prevalence in Spain & Uniform $(0.50-0.70)$ & Raaperi et al., 2014 \\
\hline Herd prevalence in Catalonia & Uniform $(0.27-0.57)$ & Benavides et al., 2018 \\
\hline Herd prevalence in Galicia & Uniform $(0.06-0.11)$ & Benavides et al., 2018 \\
\hline Infected animal (<24 mo) & Uniform $(0.15-0.20)$ & Santman Berends et al., 2018 \\
\hline Infected animal (>24 mo) & Uniform $(0.53-0.58)$ & Santman Berends et al., 2018 \\
\hline Sensitivity of ELISA (Abs) & Uniform $(0.72-0.927)$ & Raaperi et al., 2014 \\
\hline Specificity of ELISA (Abs) & Uniform $(0.92-1)$ & Raaperi et al., 2014 \\
\hline Efficacy of the cleaning and disinfection & Uniform $(0.95-1)$ & Nandi et al., 2009 \\
\hline Probability of transmission from $\mathrm{AcI}^{3}$ animal & Pert $(0.1-0.15-0.2)$ & Mars et al., 2000 \\
\hline
\end{tabular}

${ }^{1} \mathrm{PI}=$ persistently infected; on average, half of the PI animals die before $1 \mathrm{yr}$ of age.

${ }^{2} \mathrm{Abs}=$ antibodies; $\mathrm{Ag}=$ antigen.

${ }^{3} \mathrm{TI}=$ transiently infected; AcI = acutely infected; LI = latently infected 
We assumed that if purchased animals shared the same transport vehicle with PI or AcI animals, the probability of infection was $100 \%$, similar to that in a model reported by Santman-Berends et al. (2017). In the case of BVDV, infection during transport would yield a TI animal, except for pregnant animals between 30 and $120 \mathrm{~d}$ of gestation. In this case, infection during transport could yield a TR cow.

The probability that at least one uninfected (healthy) purchased animal of some age group yielded an infection status due to sharing a transport vehicle with a PI or AcI animal from each country/area was estimated using equation [7] (Appendix Table A2). In the case of BoHV-1, we considered that animals greater or less than 24 mo would have the same probability of being infected; thus, the age group calculation was not included. An active infection of $1 \%$ of the BoHV-1 seropositive animals was assumed based on SantmanBerends et al. (2018). Finally, we calculated the probability of being infected by considering the number of farms from which animals could be introduced.

\section{Probability of Infection by Being Transported in a Contaminated Vehicle}

The probability that at least one uninfected animal was infected due to being transported in a vehicle coming from some country and developing an infectious status was calculated using equation [8] (Appendix Table A2). In this equation, the following parameters were included: (1) the probability of cleaning and disinfecting the vehicle between transports, obtained in the group discussion with the field veterinarians, by the opinion of personnel working in the official veterinary services, and from the biosecurity questionnaires; (2) the efficacy of the cleaning and disinfection for BVDV as reported by Foddai et al. (2014) and for BoHV-1 based on descriptions reported by Nandi et al. (2009); and (3) BVDV survival on different surfaces reported by Stevens et al. (2011) (Appendix Table A3). We assumed that the time interval between transports had a minimum of $4 \mathrm{~h}$, a most probable value of $12 \mathrm{~h}$, and a maximum of $24 \mathrm{~h}$. These values were based on input from the veterinarians involved in the study. Survival of BoHV-1 was not included in the calculation because we considered that it can survive the whole duration of transport. Finally, the probability of infection of a susceptible animal on a contaminated surface was based on results from Niskanen and Lindberg (2003), who conducted an experiment in which 3 animals entered a pen where a PI had been previously, and 2 were infected. For BoHV-1, a value of daily aerogenic transmission of 0.15 between an infectious animal and another susceptible animal at a distance of $4 \mathrm{~m}$, as reported by Mars et al. (2000), was used as a proxy of indirect transmission.

The probability of purchasing at least one PI, TI, TR, or BoHV-1 seropositive animal was calculated by summing the probability of purchasing infected animals at origin and the probability of infection during transport.

\section{Risk Mitigation Based on Biosecurity Measures Implemented on the Farm}

Before estimating the reduction in probability arising from the implementation of biosecurity measures on the farm, we estimated the probability that one animal from the purchased batch was a PI, TI, TR, or BoHV-1 seropositive animal, considering the total number of animals of each age group introduced using a similar approach to that in equation [3.1] (Appendix Table A2). The following biosecurity measures were considered in the model.

Quarantine Period. Transiently infected animals would be infectious for up to $18 \mathrm{~d}$ (Santman-Berends et al., 2017) and would take between 2 and $4 \mathrm{~d}$ to become infectious (Muylkens et al., 2007). Thus, a duration of $>24 \mathrm{~d}$ would reduce the probability of introduction to a negligible value. For PI, TR, and BoHV-1 seropositive cattle, we did not consider the quarantine period. In addition, if the quarantine lasted $<24 \mathrm{~d}$, the probability of indirect transmission was estimated proportional to the duration (i.e., shorter durations would have a higher risk than longer durations). If tests were used in the quarantine, the probability that an animal yielded a false-negative result was calculated using an equation similar to equation [4] (Appendix Table A2).

Quarantine Routines. If farmers or farm workers were not taking care of quarantined animals at the end of the working day (i.e., last job/inspection duty of the day), the possibility of indirect transmission by fomites (i.e., boots) due to movement of farm workers was also considered. The impact of this measure was estimated by multiplying the probability that the TI or PI animal yielded a false-negative result with the survival probability of BVDV on rubber (i.e., boots) and the probability of indirect transmission (Table 1). The time interval between visiting the quarantine and the rest of the farm was about $2 \mathrm{~h}$ (with a minimum of $1 \mathrm{~h}$ and a maximum of $4 \mathrm{~h}$ ) according to field veterinarian opinion.

As a proxy for the probability of indirect transmission, the value reported in the experiment conducted by Niskanen and Lindberg (2003) for BVDV and that conducted by Mars et al. (2000) for BoHV-1 was used. In the case of TI animals, considering that they intermittently eliminate a low amount of virus (Lindberg 
and Houe, 2005; Sarrazin et al., 2014b), the probability of transmission should be very low (Table 1). A quantitative estimate for this probability was obtained following the semiquantitative methodology for import risk analysis described by the Department of Agriculture, Fisheries and Forestry (DAFF, 2004). In the case of BoHV-1, a proportion of seropositive animals that could excrete the virus during quarantine due to the stress of transportation was considered. According to Vonk Noordegraaf et al. (1998), 7\% of the seropositive cows could have a reactivated infection and excrete virus after the transport.

\section{Number of Purchased Cattle}

Finally, the annual probability of infection with BVDV or BoHV-1 due to purchasing animals was calculated by considering the number of animals introduced in each batch and the number of times animals were introduced in a 12-mo period from each country/area. Therefore, the annual probability of BVDV or BoHV-1 infection in each study farm due to purchasing animals was calculated following equation [9] (Appendix Table A2).

\section{Movements to Cattle Competitions}

Some study farms moved cattle to national or regional competitions. To participate in these competitions, animals must be certified as having tested negative for BoHV-1 antibodies and BVDV antigen. Therefore, for BVDV, the probability that false-negative PI or TI animals could attend a competition would be negligible (as the sensitivity of antigen detection test is close to $100 \%$ ). Thus, we decided to only include this scenario in the pathway for BoHV-1.

From the movement database, we extracted the number of movements to cattle competitions and the age of moved animals. Herd prevalence was assumed to be that of the region where the study farm was located (i.e., Galicia or Catalonia). Movement to competitions was assumed to be carried out using external vehicles (from a company) based on discussion with field veterinarians. For BVDV and BoHV-1, a similar approach to equation [8] (Appendix Table A2) was used to calculate the probability that animals transported to a competition were infected in a contaminated transport vehicle. In this case, animals in a transport vehicle could have 1 or 2 origins, and the maximum number of individuals loaded per farm was considered to be 4 .

For BoHV-1, the probability that the animals shared the same vehicle with false-negative AcI animals or had direct or indirect contact with false-negative AcI ani- mals at competition was calculated using a similar approach to equation [7] (Appendix Table A2). Animals returning from the competition could enter directly into the farm or be quarantined. These data were obtained from the biosecurity questionnaires to calculate the probability of BVDV and BoHV-1 infection after implementation of biosecurity measures as previously described.

\section{Reared Replacement Heifers Offsite}

Some study farms bred their own replacements offsite from the milking or lactating cattle farm. The number of these movements and age of moved animals were obtained from the movements database; calculations were performed using a similar approach to equation [8] (Appendix Table A2). When the movement was carried out using the farm's own vehicle, transport was considered to be shared with only one other farm, loading a maximum of 4 heifers. Risk mitigation derived from the quarantine was calculated as previously described. If heifers were reared in a multi-origin farm, these movements were considered as if they were from a different origin. Therefore, calculations described in the pathway for the introduction of reared replacement heifers' offsite were performed using similar approach to equation [9] (Appendix Table A2).

\section{Sensitivity Analysis}

A sensitivity analysis was performed to evaluate the influence of uncertainty of input parameters in the model output for all study farms. The Spearman correlation coefficient was selected for these calculations. In addition, in all farms, 3 uncertain input parameters were tested. The first parameter was herd prevalence and prevalence of infected animals; the second parameter was the number of visited farms in each country/ area and loaded animals in each farm. For the sensitivity analysis, both parameters were reduced to half of the values used as default. The third parameter was the probability of cleaning and disinfection of the transport vehicle, with a range of $90 \%$ to $95 \%$, being higher than default value.

\section{Risk-Mitigating Strategies}

The effect of some biosecurity measures - quarantine, testing on origin farm, and transport - on the probability of introducing BVD or IBR was evaluated in a selected farm, as follows. (1) Quarantine fulfills following conditions: testing cattle on arrival, duration period of at least $24 \mathrm{~d}$, and quarantine is visited at the end of the 
Table 2. Description of animal movements in study farms

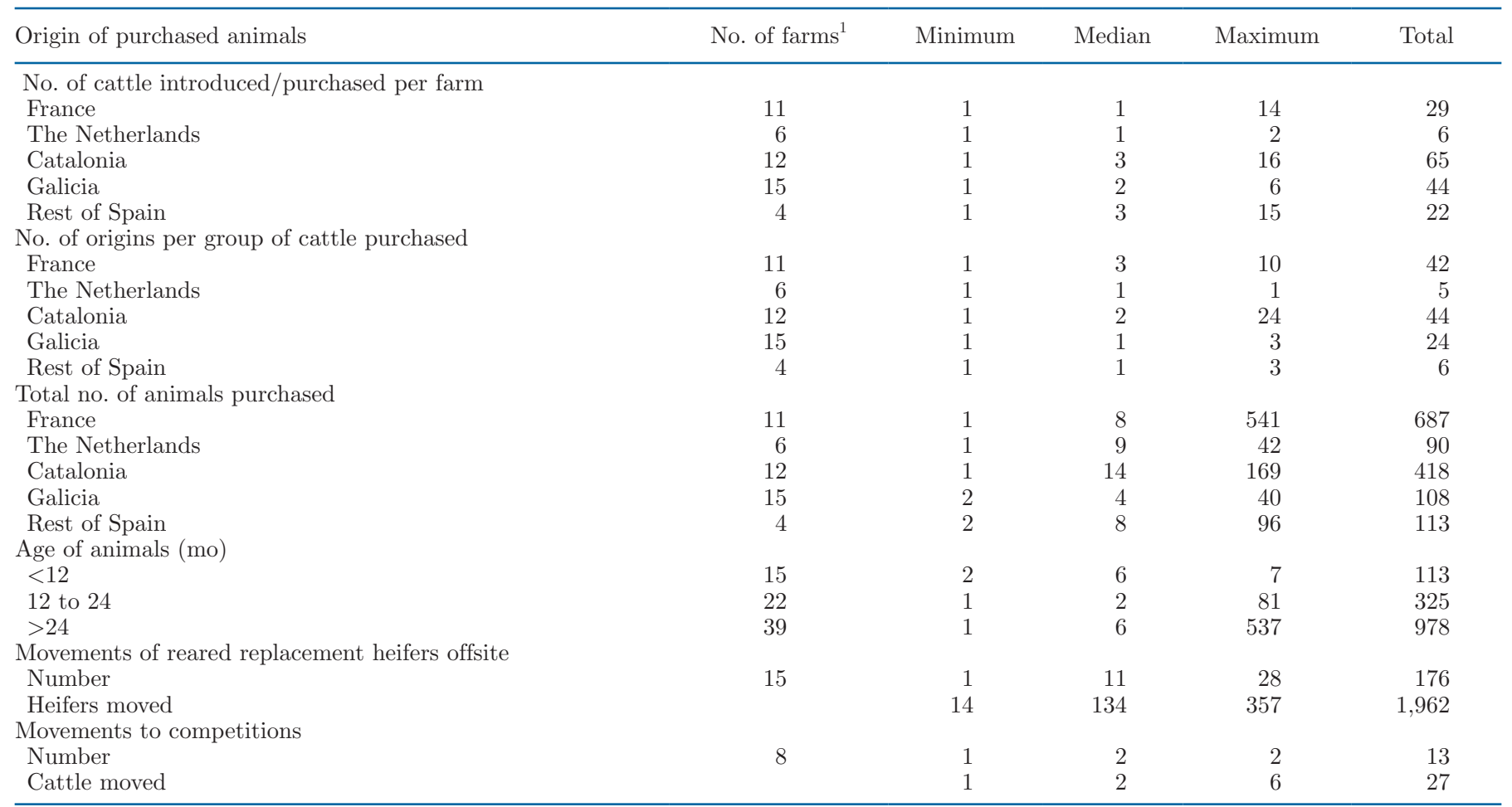

${ }^{1}$ Some farms purchased cattle from more than one location. Thus, the sum of farms is higher than the number of study farms $(\mathrm{n}=46)$.

workday. For BoHV-1, we considered a higher value for sensitivity and specificity of ELISA antibodies equal to 98.41 and $99.76 \%$, respectively (Bertolotti et al., 2015). (2) Test in origin: All purchased animals are tested before entering the farm. As previously described, higher sensitivity values were assumed for BoHV-1 ELISA. (3) Transport vehicle is not shared with animals from another farm. Figure 6 shows the effect of these riskmitigating strategies.

\section{RESULTS}

\section{Animal Movements and Biosecurity Measures}

Among 127 study farms, 46 farms that moved cattle during 2017 were included in the risk assessment model. A description of cattle movements (number of entrances, number of purchased cattle, origin, age, other factors) by study farms is shown in Table 2. Cattle transport was carried out mainly using vehicles from an external company, and several farms shared transport vehicles with cattle from other farms (Table 3 ).

Of the 36 farms that purchased animals, 50 and $39 \%$ tested the animals for BVDV and BoHV-1 at the origin farm, respectively, before transportation. Eight out of 36 farms had quarantine facilities, and 5 farms tested animals in the quarantine for both diseases. Among the 8 farms with quarantine facilities, workers visited the quarantine at the end of the workday on 6 farms, and the quarantine duration was $>24 \mathrm{~d}$ on 7 farms. Among farms with cattle returning from competitions, only one farm placed animals in quarantine facilities. Of movements made with farm-owned transports, 5 (55\%) cleaned and disinfected vehicles after being used.

Table 3. Characteristics of transport vehicles used for animal movements in study farms

\begin{tabular}{lcc}
\hline Type of movement & $\begin{array}{c}\text { No. of farms that use } \\
\text { own transport vehicle }\end{array}$ & $\begin{array}{c}\text { No. of farms that use } \\
\text { vehicles from external company }\end{array}$ \\
\hline Purchase of cattle & $2(0)^{1}$ & $34(20)$ \\
Reared replacement heifers offsite & $9(1)$ & $6(5)$ \\
Cattle competitions & 0 & $8(8)$ \\
\hline
\end{tabular}

${ }^{1}$ Values in parentheses show the number of farms that shared transport vehicles with cattle from other farms. 


\section{Probability of BVDV and BoHV-1 Introduction Through Animal Movements at the Farm Level}

The model calculated the probability of virus introduction for each farm according to their characteristics. As an example, model results from one selected farm, together with the number of movements and biosecurity measures of that farm, are shown in Figure 2 and Table 4 . The selected farm (Table 4) purchased cattle from Catalonia and other regions of Spain, attended cattle competitions, and reared replacement heifers offsite. All movements corresponded to nonpregnant cattle. The risk assessment model estimated that the farm had a high annual probability of introduction of BVDV and BoHV-1, with median values of 75 and $62 \%$, respectively. The purchase of cattle from other regions of Spain was the route with higher probability values for both diseases, whereas movements to cattle competitions, reared heifers offsite, and purchase of cattle from other farms in Catalonia were higher for BVDV only. Based on model results, the farm had a negligible probability of purchasing PI or TR animals (Figure 3).

As shown in Table 4, different biosecurity measures could be implemented to reduce the probability of introducing BVDV or BoHV-1 infected animals into the selected farm. The purchase of new animals was conducted without any testing before movement and, more importantly, they were transported in a shared transport vehicle with cattle from other farms and loaded onto the farm without being quarantined. Reared replacement heifers offsite had no contact with other animals. However, transportation took place with an own-farm vehicle that was used for other farms' movements, without cleaning and disinfection after each transportation.

\section{Probability of BVDV and BoHV-1 Introduction in the 46 Dairy Farms Analyzed}

Figure 4 shows the distribution of median probability values for the 46 study farms. The annual probability of introducing BVDV or BoHV-1 infected animals was very heterogeneous, being close to 0 in some farms and close to 1 in others (Figure 4a, d). In 23 farms, the median probability of BVDV introduction was $\leq 12 \%$ (first quartile $=1.2 \%$; third quartile $=28 \%$ ) . The median probability of BoHV-1 introduction was $<9 \%$ (first quartile $=3 \%$; third quartile $=23 \%$ ). Farms that purchased cattle from their same region (i.e., local movements) had a higher probability for introduction of BVDV and BoHV-1, followed by farms that introduced animals from other regions of Europe, reared replacement heifers offsite, or showed cattle in competitions (Figure 4a, d).
Sharing transport vehicles with other farms resulted in a higher probability of infection for most study farms, followed by transport of animals in contaminated vehi-
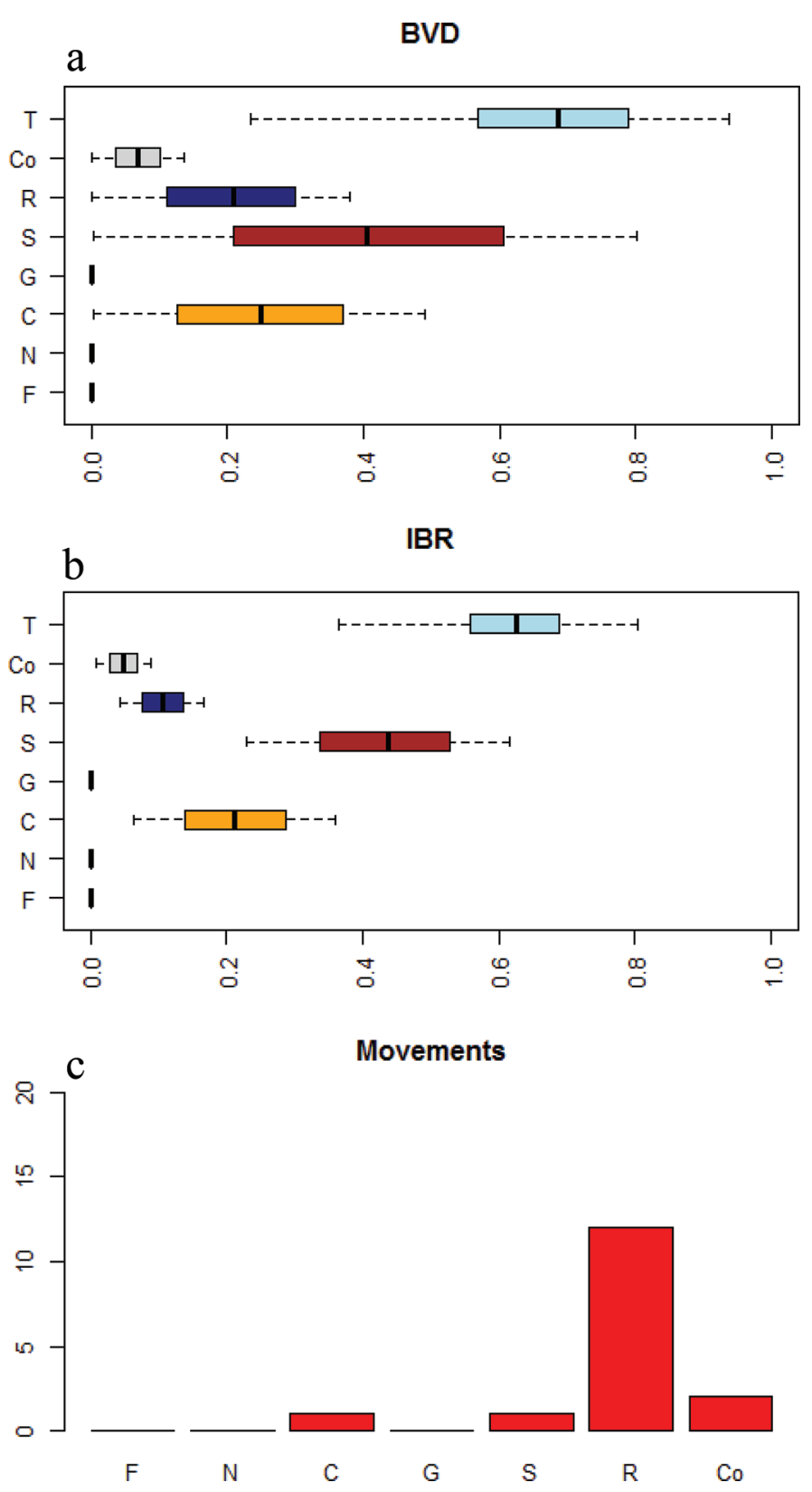

Figure 2. Probability distribution of bovine viral diarrhea (BVD) and infectious bovine rhinotracheitis (IBR) introduction for each movement performed by selected farm. Model results for (a) BVD and (b) IBR. $\mathrm{T}=$ total probability; $\mathrm{Co}=$ probability of introduction through cattle competitions; $\mathrm{R}=$ reared replacement heifers offsite; $\mathrm{S}$ $=$ purchase of cattle from Spain; $\mathrm{G}=$ purchase of cattle from Galicia; $\mathrm{C}=$ purchase of cattle from Catalonia; $\mathrm{N}=$ purchase of cattle from the Netherlands; F = purchase of cattle from France. (c) Number and type of movements: number of cattle movements from France $(\mathrm{F})$, the Netherlands (N), Catalonia (C), Galicia (G), and Spain (S); R = replacement movements, and $\mathrm{Co}=$ movements to competitions. Boxes indicate first quartile, median, and third quartile; whiskers indicate minimum and maximum. 
Table 4. Analyzed variables for one randomly selected farm ${ }^{1}$

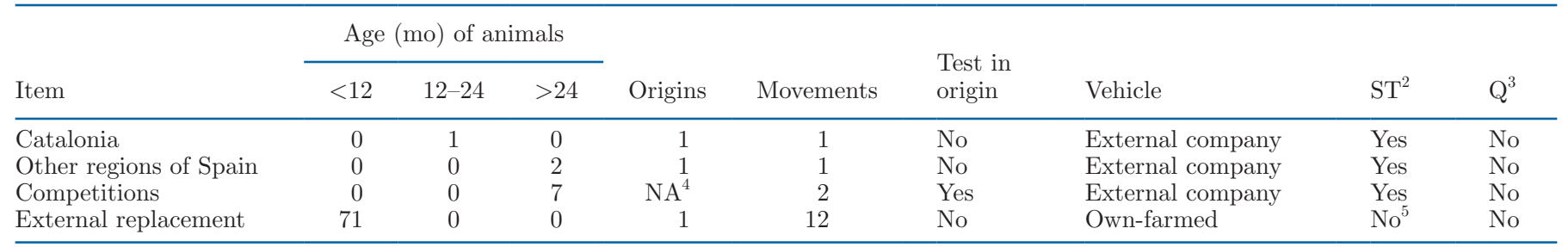

${ }^{1}$ All introduced/purchased cattle were nonpregnant animals.

${ }^{2} \mathrm{ST}=$ shared transport.

${ }^{3} \mathrm{Q}=$ quarantine.

${ }^{4}$ Not applicable.

${ }^{5}$ The vehicle was not cleaned and disinfected after animals were unloaded.

cles. The contribution of purchasing animals infected at origin was low for most study farms in the case of BVD but not IBR (Figure 4c, e). As regards BVDV infection status, in most farms, the highest probability resulted from the introduction of TI animals (Figure 4b).

\section{Sensitivity Analysis}

The Spearman correlation coefficient was close to zero in all farms for different input parameters (range from -0.04 to 0.03 ). Therefore, uncertainty in input parameters did not affect model results. However, the model results were sensitive to alterations in number of visited farms, number of loaded animals, herd prevalence, prevalence of infected animals, and probability of cleaning/disinfection of animal transport vehicle. Figure 5 shows the distribution of median probability values for the 46 study farms to alternative values to those parameters. Prevalence of infected herds and infected animals had greater influence in model results.

\section{Risk-Mitigating Strategies}

Effects of risk-mitigating strategies are shown in Figure 6 . When a selected farm met expectations described for quarantine, there was a notable reduction
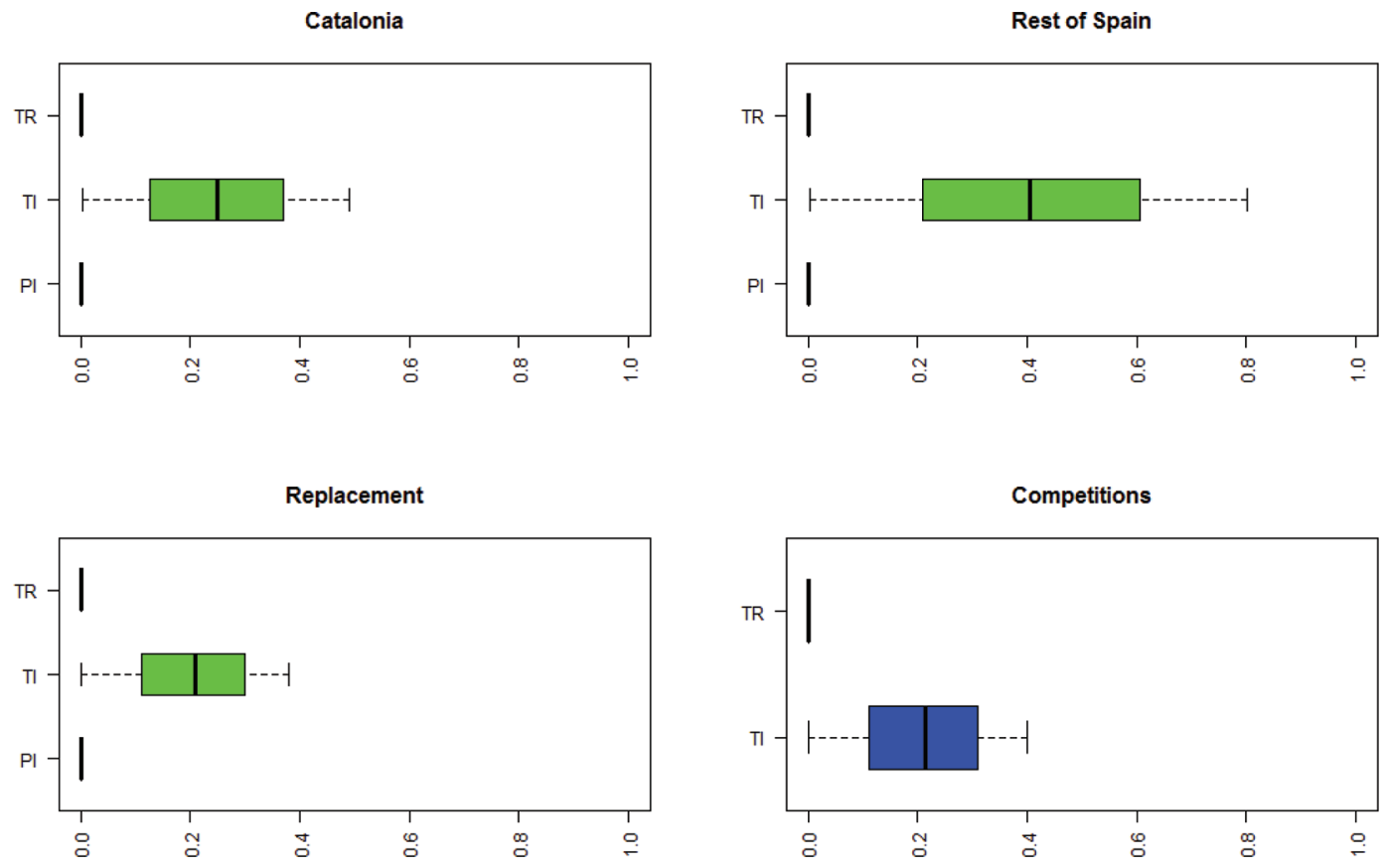

Figure 3. Probability of bovine viral diarrhea introduction in a selected farm due to movements of animals within Catalonia and rest of Spain, replacement heifers, and competitions. TR $=$ probability of Trojan cow (pregnant cow carrying a PI calf) introduction; TI $=$ probability of transiently infected cattle introduction; PI = probability of persistently infected cattle introduction. Boxes indicate first quartile, median, and third quartile; whiskers indicate minimum and maximum. 
in the probability of introducing BVDV and BoHV-1 $(<15 \%)$. Not sharing transport with cattle from other farms had a great influence in the probability of BVDV and BoHV-1 introduction, decreasing to 30 and $45 \%$, respectively. In contrast, testing all purchased animals at origin had a low effect in the probability of disease introduction for BVDV.

\section{DISCUSSION}

The risk assessment model showed that several farms had a high annual probability of introduction of BVDV and BoHV-1. Farms that purchased cattle from within their region (i.e., local movements) and shared transport with other farms had the higher probability for BVDV and BoHV-1 introduction. These results demonstrate that biosecurity practices should be improved in dairy farms from Spain.

Quantitative risk assessment models can provide an accurate estimate of the probability of virus introduction, as they consider those factors that influence the likelihood of disease transmission, such as the survival of the virus in the environment, amount of pathogen excreted, frequency of contacts, biosecurity measures,
BVD

a

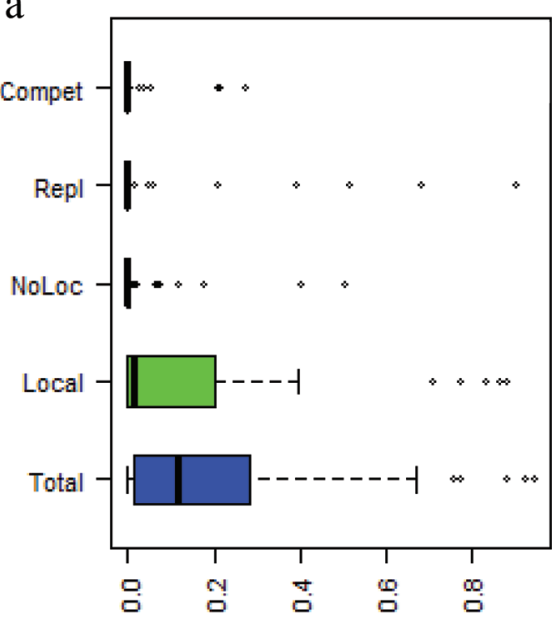

IBR

d

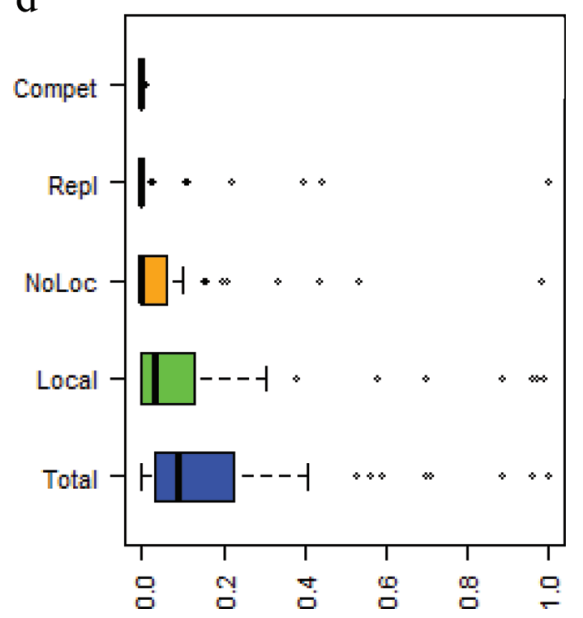

BVD by type of infection status

b

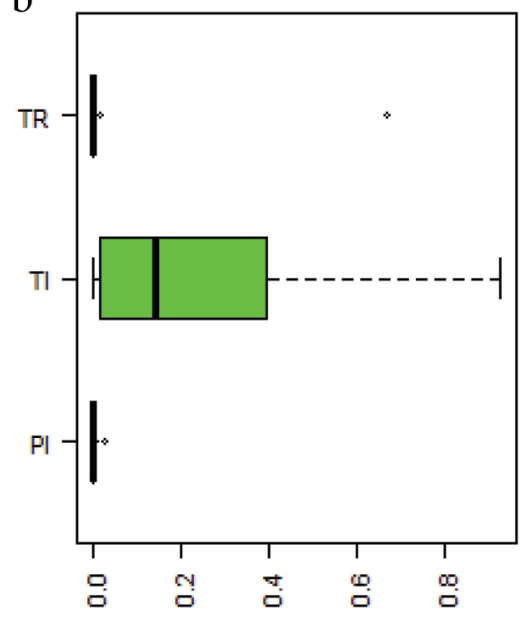

IBR by origin or transport

e

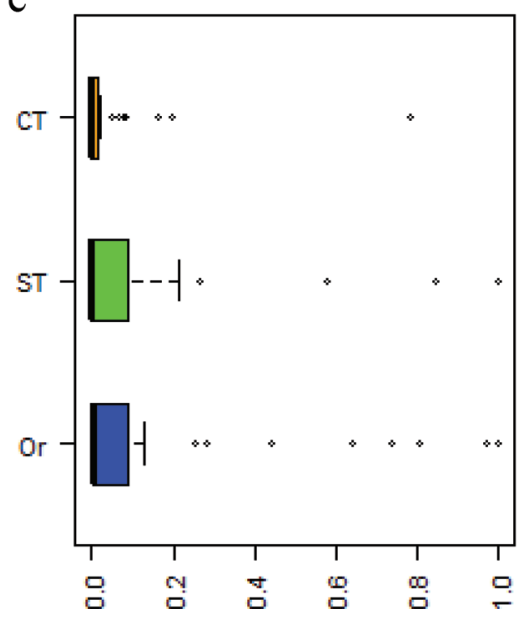

BVD by origin or transport

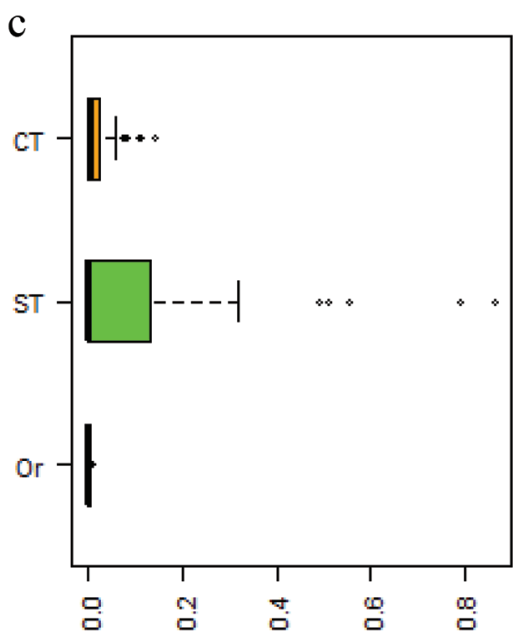

Figure 4. Distribution of median probability values of bovine viral diarrhea (BVD; a, b, c) and infectious bovine rhinotracheitis (IBR; d, e) introduction of all study farms. (a, d) Probability of BVD or IBR introduction by cattle competitions (Compet); reared replacement heifers offsite (Repl); France, Spain, and the Netherlands movements (NoLoc); Catalonia and Galicia movements (Local); and total by animal movements (Total). (b) Probability of BVD introduction by type: Trojan cows (TR, pregnant cow carrying a PI calf); transiently infected cattle (TI); and persistently infected cattle (PI). (c, e) Probability of BVD or IBR introduction by origin or transport: transport of cattle in contaminated vehicles (CT); share of transport vehicles with other farms (ST); and animal infected in origin (Or). Boxes indicate first quartile, median, and third quartile; whiskers indicate minimum and maximum; and circles indicate outliers. 
and other factors that can modify the probability of transmission for a given contact. Consequently, these kinds of models have a higher degree of complexity and need quantitative data that are not always available. Most of the developed models that measure biosecurity at the farm level in cattle and other species have been based only on opinions and perceptions and do not provide an estimate of probability of disease introduction (Julio Pinto and Urcelay, 2003; Holtkamp et al., 2013; Laanen et al., 2013; Allepuz et al., 2018). Such models can be very useful as educational tools, for developing skills in risk-based prioritization, and increasing awareness (Sternberg-Lewerin et al., 2015), as well as to benchmark farms in relation to their biosecurity level (Dewulf and van Immerseel, 2018). However, they cannot be used to assess probability of virus introduction or to identify measures that should be prioritized based on their impact on that probability.

The use of quantitative risk assessment models can be useful to promote the improvement of biosecurity in dairy cattle farms and support disease control programs. However, complexity and lack of understanding of the logic behind development of quantitative risk analysis models by end-users (e.g., field veterinarians) hampers use of these models in practice, and therefore limits their effects in improving biosecurity or supporting disease control programs. We tried to overcome this issue by using a participative approach with the objective of developing a risk assessment tool that could be adapted to end-user needs. To that end, we invited field veterinarians to identify input parameters of the model, obtain some data (e.g., that related to animal transport practices), and evaluate the reliability of the obtained results. Successful implementation of biosecurity programs requires the participation of farmers, industry, and veterinarians (Barkema et al., 2015), so further efforts to discuss model results and, if needed, to incorporate suggested modifications with these stakeholders would be of paramount importance to improve biosecurity.

A parameter with a high degree of uncertainty was BVDV and BoHV-1 herd prevalence in Spain. We combined reported data in several epidemiological studies to consider differences between places with or without voluntary control programs for both diseases. Currently, in Spain, BVDV and BoHV-1 control programs are voluntary, and only implemented in some regions. In fact, in Galicia (northwestern Spain), the program for both diseases is voluntary (Lindberg et al., 2006; Eiras et al., 2009). However, since September 2019, a volun-
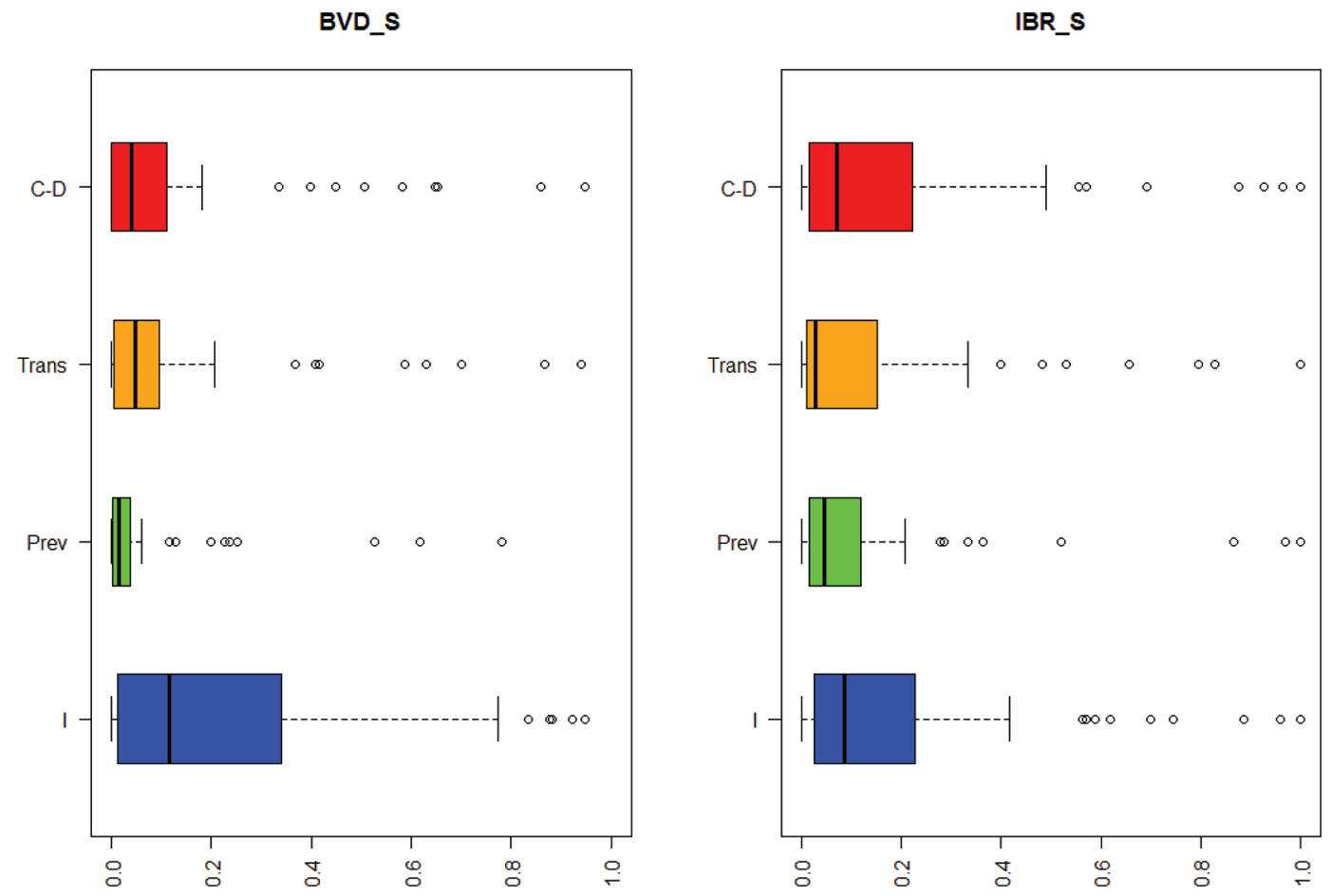

Figure 5. Distribution of median probability values of all study farms of bovine viral diarrhea virus (BVD_S) and infectious bovine rhinotracheitis (IBR_S) introduction with alternative values. I = initial probability of introduction with default values; Prev $=$ lower herd prevalence and infected animals' prevalence (i.e., half of default values); Trans $=$ lower number of farms visited in each country/area and lower number of animals loaded in each farm (i.e., half of default values); C-D = higher probability of cleaning/disinfection of transport vehicle (i.e., range of 90 to $95 \%$ ). Boxes indicate first quartile, median, and third quartile; whiskers indicate minimum and maximum; and circles indicate outliers. 
BVD_R

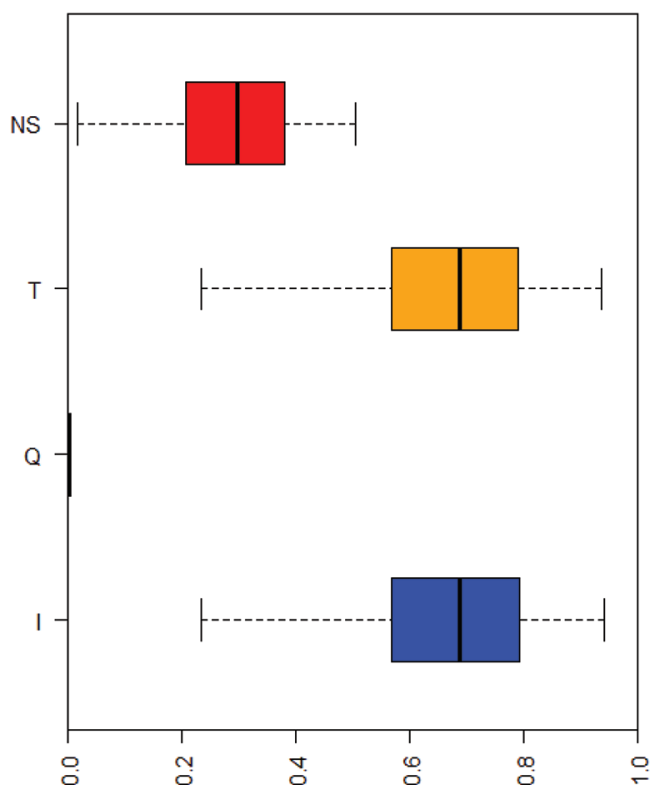

IBR_R

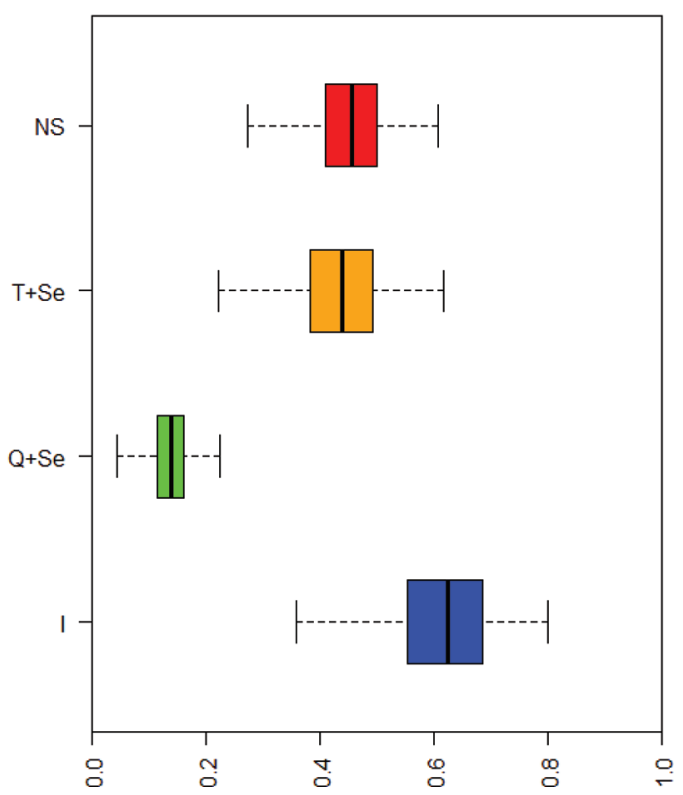

Figure 6. Reduction in probability of bovine viral diarrhea virus (BVD_R) and infectious bovine rhinotracheitis (IBR_R) introduction by implementation of biosecurity measures in selected farm. I = initial probability of introduction with default values; $\mathrm{Q}=\mathrm{quarantine} ; \mathrm{Q}+\mathrm{Se}=$ quarantine and higher sensitivity of antibody ELISA; $\mathrm{T}=$ test in origin; $\mathrm{T}+\mathrm{Se}=$ test in origin using antibody ELISA with higher sensitivity; $\mathrm{NS}=$ animal transport vehicle not shared with other farms. Boxes indicate first quartile, median, and third quartile; whiskers indicate minimum and maximum.

tary control program for BoHV-1 has been created in Spain (Royal Decree 554/2019; BOE, 2019). Because of the lack of recent studies on herd prevalence in different regions of Spain, this parameter ranged between 26 and $71 \%$. Consequently, the probability of virus introduction through this route had a very wide distribution. Reducing uncertainty around the herd prevalence of BVDV and BoHV-1 infected herds would help increase the accuracy of the model results.

In relation to cattle transport, we had information only on moved animals but no specific information about routines of the cattle transport vehicle (e.g., number of farms visited per day, number of animals by transport vehicle). Lack of availability of this data is common in other countries in Europe, as reported previously in other studies (Bronsvoort et al., 2008; Santman-Berends et al., 2018). Consequently, in this study, the information was obtained through discussions held with attending veterinarians. The sensitivity analysis demonstrated that variation in these parameters influenced the model results. Therefore, incorporation of data from animal transport companies in the risk assessment model would increase the accuracy of the estimations.

Interestingly, model results highlighted the important role of the animal transport vehicles in the spread of these viruses between dairy cattle farms, especially in the case of local movements when purchasing replacement heifers. In addition, testing animals at origin did not have a great influence in reducing the probability of disease introduction, as shown in the analysis conducted on one selected farm. This lack of efficiency was also related to the role of animal transport, because negative animals at origin could become infected during transport. On the one hand, as a voluntary control program for both diseases, there are no legal requirements to transport cattle in relation to their health status. On the other hand, cleaning and disinfection of transport vehicles is compulsory but the efficacy is probably low, and sometimes not applied. Efforts to develop more adequate disinfection points within Spain and more rigorous monitoring would be beneficial in reducing the probability of disease transmission through contaminated vehicles, as demonstrated by previous studies that include international transport (Bronsvoort et al., 2008; Fountain et al., 2018). Furthermore, animal transports in which cattle from different farms were mixed was quite common and increased the probability of disease introduction in several farms. The low number of animals moved by some farms hampers the possibility of not mixing due to economic reasons. Further discussion is needed to evaluate how this practice 
could be reduced without compromising the viability of transport companies.

In the model, we assumed that all animals that shared transport vehicle with a PI or AcI animal became infected. This represents a worst-case situation because the limited duration of transport does not necessarily result in all cattle being infected by the PI or AcI animal. First, efficient transmission of BVDV from acutely infected animals may require exposure to higher viral loads or for a longer period (Falkenberg et al., 2018). Second, in BoHV-1 infections, latently infected animals can reactivate due to transportation stress, posing a similar risk to that of AcI animals. In addition, transport periods less than $8 \mathrm{~h}$ represent a short period in which to become infected and then progress to the subsequent infectious status (Santman-Berends et al., 2018). In the model, we assumed the duration of animal transport was not enough for reactivation and we only considered it during quarantine.

Participation in competitions did not represent a significant probability of disease introduction for most of the farms attending competitions, similar to the situation in Denmark for participation in international competitions (Foddai et al., 2014). The exception could be in relation to BVDV when sending pregnant cattle between 30 and $120 \mathrm{~d}$ of gestation to these competitions. Therefore, the probability of introducing TR cattle due to movements to cattle competitions could be avoided simply by not sending pregnant cattle to competitions. However, some researchers have found that allowing cattle to return to the farm after competitions is a risk factor for the introduction of BoHV-1 and BVDV (van Wuijckhuise et al., 1998; Houe, 1999). For BoHV1 , the gathering of large numbers of cattle is a stress factor that could result in virus reactivation, and the overcrowded barn would facilitate spread of infectious diseases. Moreover, cattle returning to farm of origin could infect other cattle on the farm (van Schaik et al., 1999). Nevertheless, compulsory testing of all animals attending cattle competitions reduced the probability of disease introduction by this route, with the vehicle for animal transport again being the most critical point to be infected.

This study had some limitations. First, the participation of farms was voluntary, so our sample was not fully representative of dairy farms in Spain. However, in this study, we intended to develop a risk assessment model to improve biosecurity rather than providing an estimate of the probability of disease introduction in dairy farms from these areas. Second, only one experimental study (Niskanen and Lindberg 2003) was available for the probability of indirect transmission of BVDV (i.e., infection due to contact with contaminated surfaces).
In addition, to our knowledge, there are no studies for BoHV-1 on the probability of indirect transmission and survival of virus in different materials. The virus is stable for $1 \mathrm{mo}$ at $4^{\circ} \mathrm{C}$, can be inactivated at $37^{\circ} \mathrm{C}$ within $10 \mathrm{~d}$ and at $22^{\circ} \mathrm{C}$ within $50 \mathrm{~d}$, and may survive for more than $30 \mathrm{~d}$ in foodstuffs (Nandi et al., 2009). Thus, based on reported resistance in the environment, we assumed that the virus would survive between movements. In the same way, we did not find data on efficacy of cleaning and disinfection for BoHV-1 and, based on the virus characteristics described by Straub (1990), we assumed that efficacy of conventional disinfectants was high. Further studies analyzing how these viruses are transmitted would be beneficial to develop more accurate models.

In the studied farms, the probability of introducing BVDV and BoHV-1 could be reduced by the implementation of biosecurity measures. Despite the inherent limitations of the developed model, we believe that the model is a useful tool that supports decision-making on which biosecurity measures should be prioritized in dairy cattle herds to reduce the probability of introduction of these viruses. Further efforts should be made to estimate the probability of virus introduction through other routes, such as movement of people, non-animal transport, and so on, to obtain a complete scenario for each farm.

\section{CONCLUSIONS}

The quantitative risk assessment tool developed here allows biosecurity measures to be prioritized at the farm level based on the probability of the introduction of BVDV and BoHV-1 through cattle movements and the effect of these biosecurity measures on such probability. This approach can support decision-making in the development of biosecurity programs according to farm-specific risks. The model demonstrated the high probability of introduction of these viruses in some farms, especially through animal transport. Efforts should be devoted to reviewing animal transport practices to reduce this probability.

\section{ACKNOWLEDGMENTS}

This work was supported by a Grant from the Ministerio de Ciencia e Innovación of Spain (AGL2016-77269C2-1-R and AGL2016-77269-C2-2-R). The Universidad de Nariño (Pasto, Colombia) provided funding to the first author (BBB). The authors extend special thanks to the veterinarians who collaborated in this project. The authors have not stated any conflicts of interest. 


\section{REFERENCES}

Allepuz, A., G. E. Martín-Valls, J. Casal, and E. Mateu. 2018. Development of a risk assessment tool for improving biosecurity on pig farms. Prev. Vet. Med. 153:56-63. https://doi.org/10.1016/j prevetmed.2018.02.014.

Almeida, L. L., I. Miranda, H. Hein, W. Santiago Neto, E. Costa, F. Marks, C. Rodenbusch, C. Canal, and L. Corbellini. 2013. Herdlevel risk factors for bovine viral diarrhea virus infection in dairy herds from Southern Brazil. Res. Vet. Sci. 95:901-907. https://doi .org/10.1016/j.rvsc.2013.08.009.

Bachofen, C., H. Stalder, H. R. Vogt, M. Wegmüller, M. Schweizer, R. Zanoni, and E. Peterhans. 2013. Bovine viral diarrhea (BVD): from biology to control. Berl. Munch. Tierarztl. Wochenschr. 126:452-461. https://doi.org/10.2376/0005-9366-126-452.

Barkema, H. W., M. A. G. von Keyserlingk, J. P. Kastelic, T. J. G. M. Lam, C. Luby, J.-P. Roy, S. J. LeBlanc, G. P. Keefe, and D.F. Kelton. 2015. Invited review: Changes in the dairy industry affecting dairy cattle health and welfare. J. Dairy Sci. 98:7426-7445. https://doi.org/10.3168/jds.2015-9377.

Benavides, B., A. O. Allepuz, E. Yus, J. Casal, S. J. Moya, and F. J. Diéguez. 2018. Sanitary status against bovine viral diarrhea and infectious bovine rhinotracheitis and biosecurity measures applied in dairy farms in Catalonia and Galicia. Pages 576-577 in Proc. 15th ISVEE Symp., Chiang Mai, Thailand. International Symposium of Veterinary Epidemiology and Economics. http://isvee.net/ wp-content/uploads/2018/10/ISVEE15_Abstract-BOOK.pdf.

Bertolotti, L., E. Muratore, C. Nogarol, C. Caruso, L. Lucchese, M. Profiti, L. Anfossi, L. Masoero, S. Nardelli, and S. Rosati. 2015. Development and validation of an indirect ELISA as a confirmatory test for surveillance of infectious bovine rhinotracheitis in vaccinated herds. BMC Vet. Res. 11:300. https://doi.org/10.1186/ s12917-015-0612-5.

BOE (Boletín Oficial del Estado). 2019. Real Decreto 554/2019, de 27 de septiembre, por el que se establecen las bases de las actuaciones de prevención, control y erradicación de la rinotraqueítis infecciosa bovina y se establece un programa nacional voluntario de lucha contra dicha enfermedad. Pages 111892-111906 in BOE no. 245 , de 11 de octubre de 2019. Accessed Oct. 14, 2019. https://www .boe.es/eli/es/rd/2019/09/27/554.

Brennan, M. L., and R. M. Christley. 2012. Biosecurity on cattle farms: A study in north-west England. PLoS One 7:e28139. https: //doi.org/10.1371/journal.pone.0028139.

Bronsvoort, B. M., L. Alban, and M. Greiner. 2008. Quantitative assessment of the likelihood of the introduction of classical swine fever virus into the Danish swine population. Prev. Vet. Med. 85:226-240. https://doi.org/10.1016/j.prevetmed.2008.01.013.

DAFF. 2004. Generic import risk analysis (IRA) for PIG MEAT: Final import risk analysis report. In: Biosecurity Australia, Canberra. 28. Accessed Nov. 18, 2018. https://www.agriculture.gov.au/sites/ default/files/sitecollectiondocuments/ba/memos/2004/animal/ 2004-01c.pdf.

Dewulf, J., and F. van Immerseel. 2018. General principles of biosecurity in animal production and veterinary medicine, in: Biosecurity in animal production and veterinary medicine. J. Dewulf and F. Van Immerseel, ed. Acco Leuven Publishers, Leuven, Belgium.

Eiras, C., F. J. Diéguez, M. L. Sanjuan, E. Yus, and I. Arnaiz. 2009. Prevalence of serum antibodies to bovine herpesvirus-1 in cattle in Galicia (NW Spain). Span. J. Agric. Res. 7:800-806. https://doi .org/10.5424/sjar/2009074-1094.

Ezanno, P., C. Fourichon, A. F. Viet, and H. Seegers. 2007. Sensitivity analysis to identify key-parameters in modelling the spread of bovine viral diarrhoea virus in a dairy herd. Prev. Vet. Med. 80:49-64. https://doi.org/10.1016/j.prevetmed.2007.01.005.

Falkenberg, S. M., R. P. Dassanayake, J. D. Neill, and J. F. Ridpath. 2018. Evaluation of bovine viral diarrhea virus transmission potential to naïve calves by direct and indirect exposure routes. Vet. Microbiol. 217:144-148. https://doi.org/10.1016/j.vetmic.2018.03 .012 .

Foddai, A., A. Boklund, A. Stockmarr, K. Krogh, and C. Enøe. 2014 Quantitative assessment of the risk of introduction of bovine viral diarrhea virus in Danish dairy herds. Prev. Vet. Med. 116:75-88. https://doi.org/10.1016/j.prevetmed.2014.05.005.

Fountain, J., R. Woodgate, L. Rast, and M. Hernández-Jover. 2018. Assessing biosecurity risks for the introduction and spread of diseases among commercial sheep properties in New South Wales, Australia, using foot-and-mouth disease as a case study. Front. Vet. Sci. 5:80. https://doi.org/10.3389/fvets.2018.00080.

Gache, K., D. Ngwa-Mbot, S. Mémeteau, S. Wendling, S. Valas, and J. Vialard. 2014. Report on regulatory and voluntary surveillance of infectious bovine rhinotracheitis in 2013/2014: A stable situation and new opportunities. Pages 32-35 in Bulletin épidémiologique, animal health and nutrition No. 71/Focus on regulated and emerging diseases (REDs). Accessed May 2, 2019. https://be.anses.fr/ sites/default/files/BEP-mg-BE71-eng-art7.pdf.

GD Animal Health. 2018. Highlights Report Cattle. First quarter 2018. Animal Health situation in the Netherlands. Infectious Bovine Rhinotracheitis (IBR). 2018. Accessed May 12, 2019. https:/ /www.gdanimalhealth.com/monitoringsurveillance.

GDS. 2017. GDS infos 63: Nouvel Arrêté Ministériel IBR: en route vers l'éradication.12-15. Accessed May. 2, 2019. https://www.gds63 .com/images/pdf/GDS-INFOS-2017.pdf.

Gómez-Pacheco, J. M., C. Tarradas, I. Luque, A. J. Arenas-Casas, J. L. Maldonado-Borrego, M. A. González, and A. Perea-Remujo. 2009. Seroprevalencia de las infecciones por el virus Diarrea Vírica Bovina en ganado bovino en Andalucía. Rev. Electron. Vet. 10:2.

Hage, J. J., Y. H. Schukken, T. Dijkstra, H. W. Barkema, P. H. H Van Valkengoed, and G. H. Wentink. 1998. Milk production and reproduction during a subclinical bovine herpesvirus 1 infection on a dairy farm. Prev. Vet. Med. 34:97-106. https://doi.org/10.1016/ S0167-5877(97)00088-3.

Hanon, J. B., M. De Baere, C. de la Ferté, S. Roelandt, G. Guillot, Y. Van der Stede, and B. Cay. 2018. Serological monitoring on milk and serum samples in a BVD eradication program: A field study in Belgium showing antibody ELISA performances and epidemiological aspects. Prev. Vet. Med. 160:136-144. https://doi.org/10.1016/ j.prevetmed.2018.07.008.

Hilbe, M., H. Stalder, E. Peterhans, M. Haessig, M. Nussbaumer, C. Egli, C. Schelp, K. Zlinszky, and F. Ehrensperger. 2007. Comparison of five diagnostic methods for detecting bovine viral diarrhea virus infection in calves. J. Vet. Diagn. Invest. 19:28-34. https:// doi.org/10.1177/104063870701900105.

Holtkamp, D. J., H. Lin, C. Wang, and D. D. Polson. 2013. Development and validation of an objective risk scoring system for assessing the likelihood of virus introduction in porcine reproductive and respiratory syndrome virus-free sow farms in the US. Open J. Vet. Med. 03:168-175. https://doi.org/10.4236/ojvm.2013.32026.

Houe, H. 1999. Epidemiological features and economical importance of bovine virus diarrhoea virus (BVDV) infections. Vet. Microbiol. 64:89-107. https://doi.org/10.1016/S0378-1135(98)00262-4.

Joly, A., C. Fourichon, and F. Beaudeau. 2005. Description and first results of a BVDV control scheme in Brittany (western France) Prev. Vet. Med. 72:209-213. https://doi.org/10.1016/j.prevetmed .2005.07.016.

Julio Pinto, C., and S. V. Urcelay. 2003. Biosecurity practices on intensive pig production systems in Chile. Prev. Vet. Med. 59:139-145. https://doi.org/10.1016/S0167-5877(03)00074-6.

Laanen, M., D. Maes, C. Hendriksen, P. Gelaude, S. De Vliegher, Y. Rosseel, and J. Dewulf. 2014. Pig, cattle and poultry farmers with a known interest in research have comparable perspectives on disease prevention and on-farm biosecurity. Prev. Vet. Med. 115:1-9 https://doi.org/10.1016/j.prevetmed.2014.03.015.

Laanen, M., D. Persoons, S. Ribbens, E. de Jong, B. Callens, M. Strubbe, D. Maes, and J. Dewulf. 2013. Relationship between biosecurity and production/antimicrobial treatment characteristics in pig herds. Vet. J. 198:508-512. https://doi.org/10.1016/j.tvjl 2013.08 .029 .

Lassen, B., T. Orro, A. Aleksejev, K. Raaperi, T. Järvis, and A. Viltrop. 2012. Neospora caninum in Estonian dairy herds in relation to herd size, reproduction parameters, bovine virus diarrhoea virus, and bovine herpes virus 1. Vet. Parasitol. 190:43-50. https:/ doi.org/10.1016/j.vetpar.2012.05.021. 
Lazic, S., T. Petrovic, D. Lupulovic, and M. Jovicin. 2003. Significance of latent bovine infection due to IBR virus and its reactivation by corticosteroids. Biotechnol. Anim. Husb. 19:91-96.

Lindberg, A., J. Brownlie, G. J. Gunn, H. Houe, V. Moennig, H. W. Saatkamp, T. Sandvik, and P. S. Valle. 2006. The control of bovine viral diarrhoea virus in Europe: Today and in the future. Rev. Sci. Tech. 25:961-979. https://doi.org/10.20506/rst.25.3.1703.

Lindberg, A., and H. Houe. 2005. Characteristics in the epidemiology of bovine viral diarrhea virus (BVDV) of relevance to control Prev. Vet. Med. 72:55-73. https://doi.org/10.1016/j.prevetmed .2005.07.018.

Lindberg, A. L., and S. Alenius. 1999. Principles for eradication of bovine viral diarrhoea virus (BVDV) infections in cattle populations. Vet. Microbiol. 64:197-222. https://doi.org/10.1016/S0378 $-1135(98) 00270-3$.

Machado, G., R. M. Egocheaga, H. E. Hein, I. C. Miranda, W. S. Neto, L. L. Almeida, C. W. Canal, M. C. Stein, and L. G. Corbellini. 2016. Bovine viral diarrhoea virus (BVDV) in dairy cattle: A matched case-control study. Transbound. Emerg. Dis. 63:e1-e13. https://doi.org/10.1111/tbed.12219.

Mars, M. H., M. C. M. De Jong, P. Franken, and J. T. Van Oirschot. 2001. Efficacy of a live glycoprotein E-negative bovine herpesvirus 1 vaccine in cattle in the field. Vaccine 19:1924-1930. https://doi .org/10.1016/S0264-410X(00)00435-7.

Mars, M. H., M. C. M. De Jong, C. Van Maanen, J. J. Hage, and J. T. van Oirschot. 2000. Airborne transmission of bovine herpesvirus 1 infections in calves under field conditions. Vet. Microbiol. 76:1-13. https://doi.org/10.1016/S0378-1135(00)00218-2.

Mars, M. H., and C. Van Maanen. 2005. Diagnostic assays applied in BVDV control in the Netherlands. Prev. Vet. Med. 72:43-48. https://doi.org/10.1016/j.prevetmed.2005.08.005.

Meyling, A., H. Houe, and A. M. Jensen. 1990. Epidemiology of bovine virus diarrhoea virus. Rev. Sci. Tech. 9:75-93. https://doi.org/10 $.20506 /$ rst.9.1.489.

Murray, N., S. C. MacDiarmid, M. Wooldridge, B. Gummow, R. S. Morley, S. E. Weber, A. Giovannini, and D. Wilson. 2004. Handbook on Import Risk Analysis for Animals and Animal Products. World Organisation for Animal Health (OIE), Paris, France.

Muylkens, B., J. Thiry, P. Kirten, F. Schynts, and E. Thiry. 2007. Bovine herpesvirus 1 infection and infectious bovine rhinotracheitis. Vet. Res. 38:181-209. https://doi.org/10.1051/vetres:2006059.

Nandi, S., M. Kumar, M. Manohar, and R. S. Chauhan. 2009. Bovine herpes virus infections in cattle. Anim. Health Res. Rev. 10:85-98. https://doi.org/10.1017/S1466252309990028.

Nardelli, S., G. Farina, R. Lucchini, C. Valorz, A. Moresco, R. Dal Zotto, and C. Costanzi. 2008. Dynamics of infection and immunity in a dairy cattle population undergoing an eradication programme for infectious bovine rhinotracheitis (IBR). Prev. Vet. Med. 85:6880. https://doi.org/10.1016/j.prevetmed.2008.01.001.

Newcomer, B. W., and D. Givens. 2016. Diagnosis and control of viral diseases of reproductive importance: Infectious bovine rhinotracheitis and bovine viral diarrhea. Vet. Clin. North Am. Food Anim. Pract. 32:425-441. https://doi.org/10.1016/j.cvfa.2016.01.011.

Niskanen, R., S. Alenius, B. Larsson, and A. Lindberg. 2000. Lack of virus transmission from bovine viral diarrhoea virus infected calves to susceptible peers. Acta Vet. Scand. 41:93-99.

Niskanen, R., and A. Lindberg. 2003. Transmission of bovine iral diarrhoea virus by unhygienic vaccination procedures, ambient air, and from contaminated pens. Vet. J. 165:125-130. https://doi.org/ 10.1016/S1090-0233(02)00161-2.

Pouillot, R., and M. L. Delignette-Muller. 2010. Evaluating variability and uncertainty separately in microbial quantitative risk assessment using two R packages. Int. J. Food Microbiol. 142:330-340. https://doi.org/10.1016/j.ijfoodmicro.2010.07.011.

Raaperi, K., T. Orro, and A. Viltrop. 2014. Epidemiology and control of bovine herpesvirus 1 infection in Europe. Vet. J. 201:249-256. https://doi.org/10.1016/j.tvjl.2014.05.040.

Reardon, F., D. Graham, T. A. Clegg, J. Tratalos, P. O'Sullivan, and S. J. More. 2018. Potential infection-control benefit of measures to mitigate the risk posed by Trojan dams in the Irish BVD eradica- tion programme. Prev. Vet. Med. 157:78-85. https://doi.org/10 $.1016 /$ j.prevetmed.2018.06.001.

Sahlström, L., T. Virtanen, J. Kyyrö, and T. Lyytikäinen. 2014. Biosecurity on Finnish cattle, pig and sheep farms-Results from a questionnaire. Prev. Vet. Med. 117:59-67. https://doi.org/10 .1016/j.prevetmed.2014.07.004.

Santman-Berends, I. M. G. A., M. H. Mars, L. Van Duijn, K. W. H. Van Den Broek, and G. van Schaik. 2017. A quantitative riskanalysis for introduction of bovine viral diarrhoea virus in the Netherlands through cattle imports. Prev. Vet. Med. 146:103-113. https://doi.org/10.1016/j.prevetmed.2017.08.003.

Santman-Berends, I. M. G. A., M. H. Mars, L. van Duijn, and G. van Schaik. 2015. Evaluation of the epidemiological and economic consequences of control scenarios for bovine viral diarrhea virus in dairy herds. J. Dairy Sci. 98:7699-7716. https://doi.org/10.3168/ jds.2014-9255.

Santman-Berends, I. M. G. A., M. H. Mars, H. W. F. Waldeck, L. Van Duijn, P. Wever, K. W. H. Van Den Broek, and G. Van Schaik. 2018. Quantification of the probability of reintroduction of IBR in the Netherlands through cattle imports. Prev. Vet. Med. 150:168175. https://doi.org/10.1016/j.prevetmed.2017.08.024.

Sarrazin, S., A. B. Cay, J. Laureyns, and J. Dewulf. 2014a. A survey on biosecurity and management practices in selected Belgian cattle farms. Prev. Vet. Med. 117:129-139. https://doi.org/10.1016/j .prevetmed.2014.07.014.

Sarrazin, S., J. Dewulf, E. Mathijs, J. Laureyns, L. Mostin, and A. B. Cay. 2014b. Virulence comparison and quantification of horizontal bovine viral diarrhoea virus transmission following experimental infection in calves. Vet. J. 202:244-249. https://doi.org/10.1016/ j.tvj1.2014.07.010.

Sayers, R. G., N. Byrne, E. O'Doherty, and S. Arkins. 2015. Prevalence of exposure to bovine viral diarrhoea virus (BVDV) and bovine herpesvirus-1 (BoHV-1) in Irish dairy herds. Res. Vet. Sci. 100:21-30. https://doi.org/10.1016/j.rvsc.2015.02.011.

SCOPAFF. 2018. Eradication of BoHV-1 in the Netherlands. Ministry of Agriculture, Nature and Food Quality. Accessed May. 14, 2019. https://ec.europa.eu/food/sites/food/files/animals/docs/reg-com _ahw_20180418_pres_bohv-1-erad_nld.pdf. pdf.

Sternberg-Lewerin, S., J. Österberg, S. Alenius, M. Elvander, C. Fellström, M. Tråvén, P. Wallgren, K. P. Waller, and M. Jacobson. 2015. Risk assessment as a tool for improving external biosecurity at farm level. BMC Vet. Res. 11:171. https://doi.org/10.1186/ s12917-015-0477-7.

Stevens, E. T., D. U. Thomson, and B. W. Wileman. 2011. The survival of bovine viral diarrhea virus on materials associated with livestock production. Bov. Pract. 45:118-123.

Straub, O. C. 1990. Infectious bovine rhinotracheitis virus. Pages 71-108 in Virus Infections of Ruminants. Elsevier B. V., Amsterdam, the Netherlands. https://doi.org/10.1016/b978-0-444-87312 $-5.50020-5$.

van Duijn, L., A. M. B. Veldhuis, M. H. Mars, B. de Roo, and T. J. G. M. Lam. 2019. Efficacy of a voluntary BVDV control programme: Experiences from the Netherlands. Vet. J. 245:55-60. https://doi .org/10.1016/j.tvjl.2018.12.016.

van Schaik, G., A. A. Dijkhuizen, G. Benedictus, H. W. Barkema, and J. L. Koole. 1998. Exploratory study on the economic value of a closed farming system on Dutch dairy farms. Vet. Rec. 142:240242. https://doi.org/10.1136/vr.142.10.240.

van Schaik, G., Y. H. Schukken, M. Nielen, A. A. Dijkhuizen, H. W. Barkema, and G. Benedictus. 2002. Probability of and risk factors for introduction of infectious diseases into Dutch SPF dairy farms: A cohort study. Prev. Vet. Med. 54:279-289. https://doi.org/10 .1016/S0167-5877(02)00004-1.

van Schaik, G., Y. H. Schukken, M. Nielen, A. A. Dijkhuizen, and R. B. Huirne. 1999. Application of survival analysis to identify management factors related to the rate of BHV1 seroconversions in a retrospective study of Dutch dairy farms. Livest. Prod. Sci. 60:371-382. https://doi.org/10.1016/S0301-6226(99)00107-4.

Van Wuijckhuise, L., J. Bosch, P. Franken, K. Frankena, and A. Elbers. 1998. Epidemiological characteristics of bovine herpesvirus 
1 infections determined by bulk milk testing of all Dutch dairy herds. Vet. Rec. 142:181-184. https://doi.org/10.1136/vr.142.8 .181 .

Vonk Noordegraaf, A., J. A. A. M. Buijtels, A. A. Dijkhuizen, P. Franken, J. A. Stegeman, and J. Verhoeff. 1998. An epidemiological and economic simulation model to evaluate the spread and control of infectious bovine rhinotracheitis in the Netherlands. Prev. Vet. Med. 36:219-238. https://doi.org/10.1016/S0167-5877(98)00081 -6 .

Wells, S. J. 2000. Biosecurity on dairy operations: Hazards and risks. J. Dairy Sci. 83:2380-2386. https://doi.org/10.3168/jds.S0022 $-0302(00) 75127-7$

\section{APPENDIX}

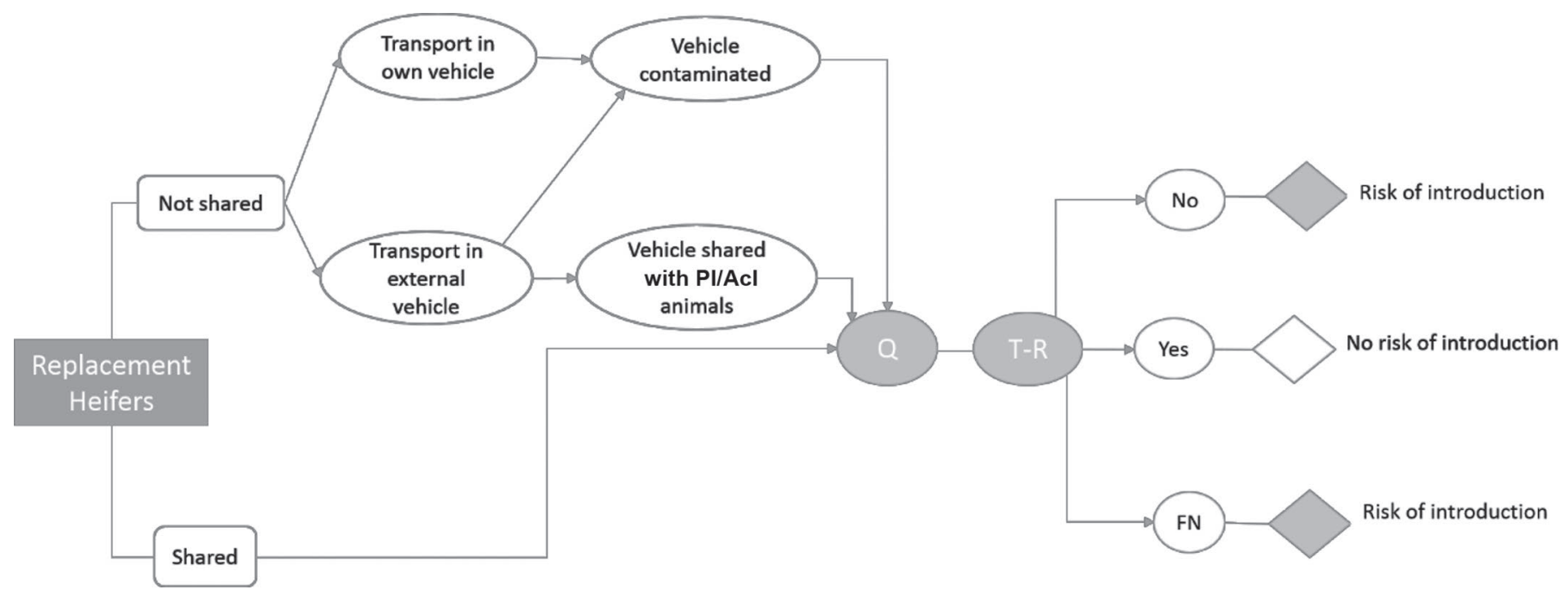

Figure A1. Pathway of entrance according to types that reared replacement heifers offsite. Shared/not shared: when place to rear heifers is shared or not with animals of other farms; PI = persistently infected with bovine viral diarrhea virus; AcI = acutely infected with bovine herpesvirus-1; $\mathrm{Q}=$ quarantine; $\mathrm{T}=$ test on quarantine; $\mathrm{R}=$ quarantine routines; $\mathrm{FN}=$ false negative. 


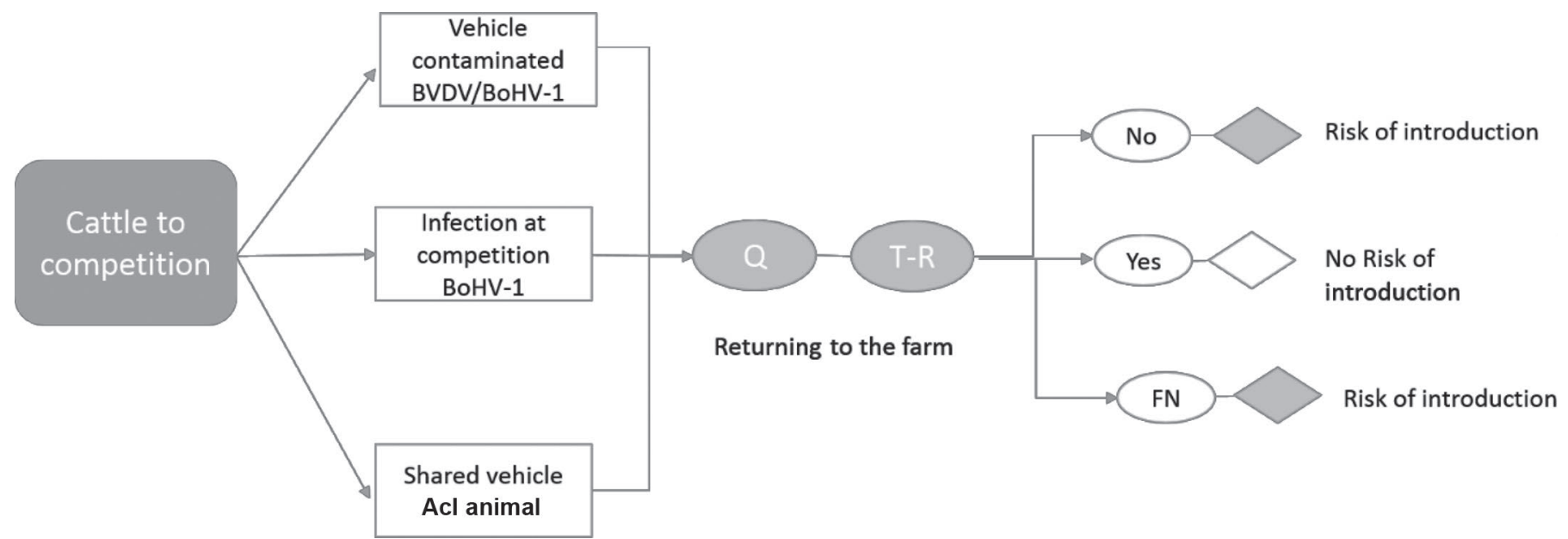

Figure A2. Pathway of entrance according to the scenarios considered for movements to cattle competitions; AcI = acutely infected with bovine herpesvirus-1 (BoHV-1); $\mathrm{Q}=$ quarantine; $\mathrm{T}=$ test on quarantine; $\mathrm{R}=$ quarantine routines; $\mathrm{FN}=$ false negative; $\mathrm{BVDV}=$ bovine viral diarrhea virus.

Table A1. Characterization of field veterinarians who participated in the discussion groups

\begin{tabular}{lcc}
\hline Background & $\begin{array}{c}\text { Years of } \\
\text { expertise }\end{array}$ & $\begin{array}{c}\text { No. of dairy } \\
\text { farms advised }\end{array}$ \\
\hline Animal health, reproduction, and bovine clinic & 40 & 25 \\
Animal health, reproduction, and technical management & 15 & 22 \\
Animal health and reproduction & 4 & 15 \\
Animal health and reproduction & 28 & 26 \\
Animal health, reproduction, and milk quality & 20 & 20 \\
\hline
\end{tabular}


Table A2. Equations used to estimate probabilities inside the model to evaluate the probability of bovine viral diarrhea virus (BVDV) and bovine herpesvirus-1 (BoHV-1) introduction in a dairy farm ${ }^{1}$

\begin{tabular}{ll}
\hline Equation & Description
\end{tabular}

Probability of purchasing an infected animal

[1] Number of animals purchased each time from country/area $i$ and age group $k$ :

$$
n(i, k)=\frac{\operatorname{animals}(i, k) / \operatorname{times}(i)}{\operatorname{farms}(i)}
$$

[2] Probability that at least one animal from a batch coming from a single farm of a certain country/area $i$ was already infected with BVDV or BoHV-1 $j$ ( $j$ indicating whether the animal was a PI, TI, TR, or BoHV-1 seropositive animal):

$$
P_{\text {inf }}(i, j)=1-[1-\operatorname{HerdPrev}(i) \times \text { WithinPrev }]^{[n(i, k) \times g e s t(i)]}
$$

[3.1] Probability that a single animal was infected:

$$
P_{\text {inf_Animal }}(i, j)=1-\left[1-P_{\text {inf }}(i, j)\right]^{\frac{1}{n}(i, k) \times \text { gest }(i)}
$$

[3.2] Expected number of BVDV and BoHV-1 animals already infected in the farm of origin:

Animals_Infected $(i, j)=P_{\text {inf_Animal }}(i, j) \times n(i, k) \times \operatorname{gest}(i)$

Probability of false negatives

[4] Probability that one infected animal yielded a false-negative result:

$$
P_{F N}(i, j)=\frac{P_{\text {inf_Animal }}(i, j) \times(1-S e)}{\left[(1-S e) \times P_{\text {inf_Animal }}(i, j)\right]+\left[S p \times\left(1-P_{\text {inf_Animal }}(i, j)\right)\right]}
$$

[5.1] Probability that at least one infected animal was present in the batch of animals:

$P_{F N \_ \text {batch }}(i, j)=1-\left[1-P_{F N}(i, j)\right]^{\text {Animals_Infected }(i, j)}$

[5.2] Probability that at least one infected animal was purchased from at least one of the farms from which animals could be introduced:

$$
P_{\text {inf_batch }}(i, j)=1-\left[1-P_{F N_{-} \text {batch }}(i, j)\right]^{\text {farms }(i)}
$$

Probability of infection during transport

[6.1] Probability of sharing a transport vehicle with at least one PI or AcI animal in country/area $i$ :

$$
P_{\text {share }}(i)=\left\{\operatorname{HerdPrev}(i) \times\left[1-\left(1-\text { WithinPrev }(i) \times P_{A c I} \text { or } P_{P I}\right)\right]\right\}^{\text {loaded }}
$$

[6.2] Probability of sharing a transport vehicle with a PI or AcI animal when purchasing animals from country/area $i$ :

$$
P_{I_{-} V}(i)=1-\left[1-P_{\text {share }}(i)\right]^{\text {Visited }}
$$

[7] Probability that at least one uninfected purchased animal of the age group $k$ yielded an infection status $j$ due to sharing transport vehicle with a PI or AcI animal from each country/area $i$ :

$$
\begin{aligned}
& P_{B V D_{\text {Shared }}}(i, j)=1-\left[1-P_{I_{-} V}(i)\right]^{[\text {healthy }(i, k) \times \text { gest }(i)]} \\
& P_{I B R_{\text {Shared }}}(i)=1-\left[1-P_{I_{-} V}(i)\right]^{\text {healthy }(i)}
\end{aligned}
$$

Probability of infection due to being transported in a contaminated vehicle

[8] Probability that at least one uninfected animal was infected due to being transported in a vehicle coming from country $i$ and developed an infectious status $j$ :

$$
\begin{aligned}
& P_{I_{-} C}(i, j)= \\
& 1-\left\{P_{I_{-} V}(i) \times C(i) \times(1-E) \times S \times P T+P_{I_{-} V}(i) \times[1-C(i)] \times S \times P T\right\}^{\text {healthy }(i, k)}
\end{aligned}
$$

Annual probability of infection by BVDV or BoHV-1 due to purchasing animals:

$$
\begin{aligned}
& {\stackrel{[9]}{P_{B V D} \text { Purchase }}}=1-\prod_{i=1}^{5}\left[1-P I_{Y}(i)\right] \times \prod_{i=1}^{5}\left[1-T I_{Y}(i)\right] \times \prod_{i=1}^{5}\left[1-T R_{Y}(i)\right] \\
& P_{I B R_{-} \text {Purchase }}=1-\prod_{i=1}^{5}\left[1-I B R_{P_{\text {Oos_Y }}}(i)\right]
\end{aligned}
$$

- animals $(i, k)$ : number of animals purchased throughout the year from country/area $i$ of group age $k$ per farm

- $\operatorname{times}(i)$ : number of times animals have been purchased from country/area $i$ in 1 yr

- $f a r m s(i)$ : number of farms from which animals can be purchased in each country/area $i$

- HerdPrev(i): herd prevalence in country/area $i$.

- WithinPrev: proportion of seropositive (BoHV-1) and viremic

(BVDV) animals

- gest $(i)$ : proportion of pregnant animals imported from country/ area $i$ (this parameter was only used for BVDV calculations and in the case of animals $>12 \mathrm{mo}$ )

- $P_{\text {inf_Animal }}$ probability that a single animal was infected

- $S e$ : sensitivity

- $S p$ : specificity

- $P_{F N}$ : probability that one infected animal yielded a falsenegative result

- Animals_Infected: expected number of BVDV and BoHV-1 animals already infected in the farm of origin

- $P_{F N \_b a t c h}:$ probability that at least one infected animal was present in the batch of animals

- $P_{A c I}:$ probability of an active infection in a group of BoHV-1 seropositive animals

- $P_{P I}$ : probability of PI animal

- loaded: number of animals loaded by farm

- $P_{\text {share }}:$ probability of sharing a transport vehicle with at least one PI or AcI animal in country/area $i$

- Visited: number of farms visited by country/area

- $P_{I-V}$ : probability of sharing a transport vehicle with a PI or AcI animal when purchasing animals from country/area $i$

- healthy: uninfected purchased animal

- gest $(i)$ : proportion of pregnant animals imported

- $P_{L-V}$ : probability of sharing a transport vehicle with a PI or AcI animal when purchasing animals from country/area $i$

- $C$ : probability of cleaning and disinfecting the vehicle between transports in country/area $i$

- $E$ : efficacy of the cleaning and disinfection

- $S$ : survival of BVDV in metal

- $P T$ : probability of infection of a susceptible animal in a contaminated surface

- $P I_{Y:}$ annual probability of purchasing at least one PI

- $T I_{Y:}$ annual probability of purchasing at least one TI

- $T R_{Y}$ : annual probability of purchasing at least one TR

- $I B R_{P o s} Y^{:}$annual probability of purchasing at least one TR

${ }^{1} \mathrm{PI}=$ persistently infected animal; $\mathrm{TI}=$ transiently infected animal; $\mathrm{TR}=$ Trojan cow (pregnant cow carrying a PI calf); AcI = acutely infected animal. 
Table A3. Probability (\%) of bovine viral diarrhea virus survival after application to the potential fomite

\begin{tabular}{|c|c|c|c|c|c|c|}
\hline \multirow[b]{2}{*}{ Fomite } & \multirow[b]{2}{*}{ Treatment $^{1}$} & \multicolumn{5}{|c|}{ Survival time } \\
\hline & & $1 \mathrm{~h}$ & $2 \mathrm{~h}$ & $4 \mathrm{~h}$ & $12 \mathrm{~h}$ & $24 \mathrm{~h}$ \\
\hline Rubber & Mucus & 88.6 & 75 & 53.6 & 10.4 & 5.6 \\
\hline Galvanized metal & Mucus & 21.5 & 9.6 & 3.9 & 0.4 & 0.2 \\
\hline Soil & Mucus & 47.9 & 26.2 & 12.0 & 1.4 & 0.7 \\
\hline
\end{tabular}

${ }^{1}$ Before application to the potential fomite, the virus was diluted in PBS that included $20 \%$ synthetic mucus. Source: Stevens et al. (2011). 